\title{
Description of 2005-10 Domestic Water Use for Selected U.S. Cities and Guidance for Estimating Domestic Water Use
}

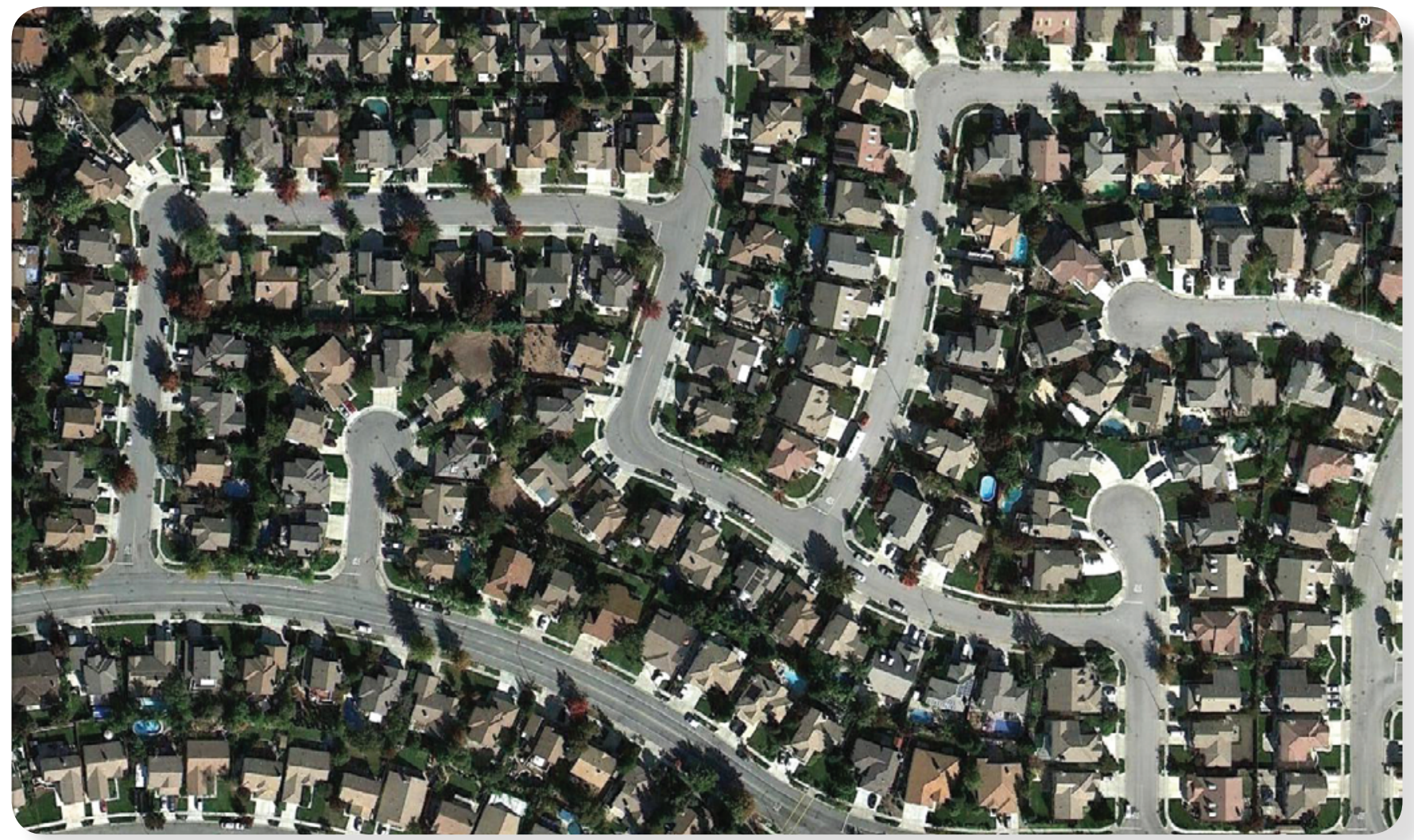

Scientific Investigations Report 2012-5163

U.S. Department of the Interior

U.S. Geological Survey 
Cover image. Image from the U.S. Geological Survey, The National Map, Gilroy, Calif., 7/30/2012.

Back cover illustration. Figure $4 A$ from this report. 


\section{Description of 2005-10 Domestic Water Use for Selected U.S. Cities and Guidance for Estimating Domestic Water Use}

By Joan F. Kenny and Kyle E. Juracek

Scientific Investigations Report 2012-5163 


\section{U.S. Department of the Interior \\ KEN SALAZAR, Secretary \\ U.S. Geological Survey \\ Marcia K. McNutt, Director}

U.S. Geological Survey, Reston, Virginia: 2012

For more information on the USGS - the Federal source for science about the Earth, its natural and living resources, natural hazards, and the environment, visit http://www.usgs.gov or call 1-888-ASK-USGS.

For an overview of USGS information products, including maps, imagery, and publications, visit http://www.usgs.gov/pubprod

To order this and other USGS information products, visit http://store.usgs.gov

Any use of trade, firm, or product names is for descriptive purposes only and does not imply endorsement by the U.S. Government.

Suggested citation:

Kenny, J.F., and Juracek, K.E., 2012, Description of 2005-10 domestic water use for selected U.S. cities and guidance for estimating domestic water use: U.S. Geological Survey Scientific Investigations Report 2012-5163, 31 p. 


\section{Contents}

Abstract

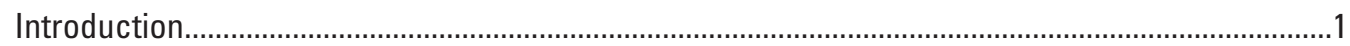

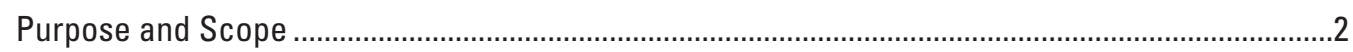

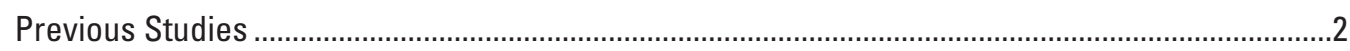

Methods

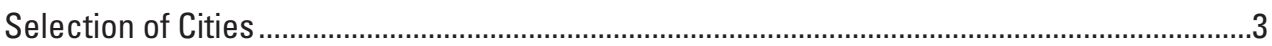

Description of Data Collected............................................................................................

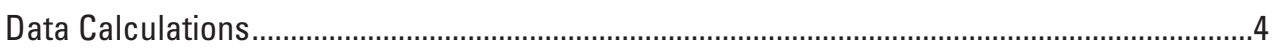

Statistical Analyses .....................................................................................................................

Description of Domestic Per Capita Water Use for Selected U.S. Cities .........................................6

Average Annual Domestic and Total Per Capita Water Use .....................................................6

Seasonal Domestic Per Capita Water Use ..................................................................................

Variables That Potentially Affect Domestic Water Use.................................................................

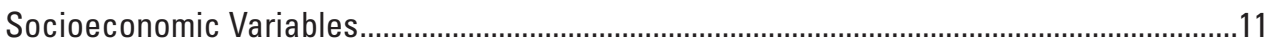

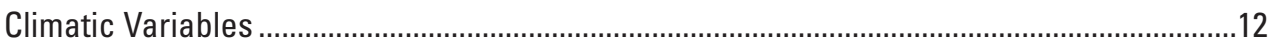

Guidance for Estimating Domestic Water Use ………...........................................................15

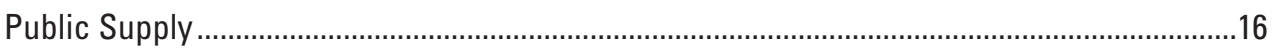

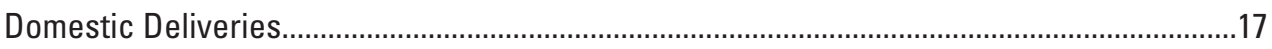

Domestic Deliveries Based on Percentage of Total Production or Sales.......................17

Domestic Deliveries Based on Per Capita Use................................................................18

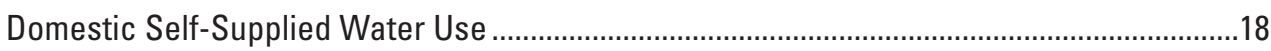

Additional Considerations for National Data Collection ......................................................19

Summary and Conclusions...................................................................................................

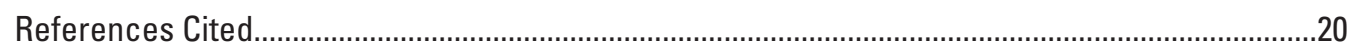

Appendix 1. Data collected and calculated for selected U.S. cities, 2005-10_................................24

Appendix 2. Weather stations used for selected U.S. cities .............................................................31

\section{Figures}

1. Map showing location of, and 2010 population served for, selected U.S. cities included in study

2. Graphs showing $(A)$ minimum, median, and maximum domestic per capita water use for selected U.S. cities, 2005-10, (B) total and domestic per capita water use for selected U.S. cities with median domestic use of 100 gallons per capita per day or more, 2005-10, $(C)$ total and domestic per capita water use for selected U.S. cities with median domestic use between 65 and 100 gallons per capita per day, 2005-10, and (D) total and domestic per capita water use for selected U.S. cities with median domestic use of less than 65 gallons per capita per day, 2005-10. 7

3. Graph showing median domestic, commercial and industrial, and other water use as percentages of total annual water use for selected U.S. cities, 2005-10 ........................9

4. Graphs showing $(A)$ median domestic per capita water use for lowest and highest consecutive 3-month periods for selected U.S. cities, 2005-10, (B) domestic per capita water use for selected U.S. cities with average difference between lowest and highest consecutive 3-month periods of more than 100 gallons per capita per day, 2005-10, and $(C)$ domestic per capita water use for selected U.S. cities with average difference between lowest and highest consecutive 3-month periods of less than 100 gallons per capita per day, 2005-10. 
5. Graphs showing $(A)$ median domestic water use as percentage of median total water use for lowest consecutive 3-month periods for selected U.S. cities, 2005-10, and $(B)$ median domestic water use as percentage of median total water use for highest consecutive 3-month periods for selected U.S. cities, 2005-10

6. Graphs showing relation and coefficient of determination $\left(R^{2}\right)$ between median annual average domestic per capita water use and $(A)$ median age, $(B)$ percentage of population age 65 and over, $(C)$ percentage of households with one or more people age 65 and over, and (D) percentage of houses built in 1939 or earlier for five selected cities in California, 2005-10.

7. Graph showing relation and coefficient of determination $\left(R^{2}\right)$ between median annual average domestic per capita water use and percentage of houses built 1940 to 1979 for five selected cities in Kansas, 2005-10.

8. Graph showing relation and coefficient of determination $\left(R^{2}\right)$ between annual mean domestic per capita water use and annual precipitation for Gresham, Wisconsin, 2005-10

9. Graph showing relation and coefficient of determination $\left(R^{2}\right)$ between annual mean domestic per capita water use and annual precipitation for Jacksboro, Texas, 2005-10.

10. Graphs showing relation and coefficient of determination $\left(R^{2}\right)$ between annual mean domestic per capita water use and $(A)$ annual maximum temperature, and $(B)$ MaySeptember maximum temperature for Miles City, Montana, 2005-10.

11. Graph showing average annual, high-3, and low-3 total per capita water use for selected U.S. cities, $2005-10$.

12. Graph showing public supply per capita water use and population served, United States, 1950-2005.

\section{Tables}

1. Water-use, socioeconomic, and climatic variables used in statistical analyses.

2. Coefficients of determination $\left(R^{2}\right)$ for median annual average domestic per capita water use compared to 18 socioeconomic variables for 20 selected U.S. cities, five selected California cities, and five selected Kansas cities, 2005-10

3. Coefficients of determination $\left(R^{2}\right)$ for annual mean domestic per capita water use compared to three climatic variables for 21 selected U.S. cities, 2005-10.

4. Coefficients of determination $\left(R^{2}\right)$ for low-3 domestic per capita water use compared to three climatic variables for 15 selected U.S. cities, 2005-10

5. Coefficients of determination $\left(R^{2}\right)$ for high-3 domestic per capita water use compared to three climatic variables for 15 selected U.S. cities, 2005-10.

\section{Conversion Factors and Abbreviations}

\begin{tabular}{lcl}
\hline \multicolumn{1}{c}{ Multiply } & \multicolumn{1}{c}{ By } & \multicolumn{1}{c}{ To obtain } \\
\hline & Volume & \\
\hline gallon (gal) & 3.785 & liter $(\mathrm{l})$ \\
gallon (gal) & 0.1337 & cubic foot $\left(\mathrm{ft}^{3}\right)$ \\
million gallons (Mgal) & 3.07 & acre-foot $(\mathrm{acre}-\mathrm{ft})$ \\
cubic foot $\left(\mathrm{ft}^{3}\right)$ & 0.02832 & cubic meter $\left(\mathrm{m}^{3}\right)$ \\
acre-foot (acre-ft) & 1,233 & cubic meter $\left(\mathrm{m}^{3}\right)$ \\
\hline
\end{tabular}




\section{Acknowledgments}

This study was supported by the U. S. Geological Survey's Groundwater Resources Program. The authors gratefully acknowledge the various individuals at State agencies and City offices whose assistance was invaluable for obtaining the water-use and related information for the selected

cities included in this study. 



\title{
Description of 2005-10 Domestic Water Use for Selected U.S. Cities and Guidance for Estimating Domestic Water Use
}

\author{
By Joan F. Kenny and Kyle E. Juracek
}

\section{Abstract}

Domestic water-use and related socioeconomic and climatic data for 2005-10 were used in an analysis of 21 selected U.S. cities to describe recent domestic per capita water use, investigate variables that potentially affect domestic water use, and provide guidance for estimating domestic water use. Domestic water use may be affected by a combination of several factors. Domestic per capita water use for the selected cities ranged from a median annual average of 43 to 177 gallons per capita per day (gpcd). In terms of year-to-year variability in domestic per capita water use for the selected cities, the difference from the median ranged from \pm 7 to \pm 26 percent with an overall median variability of \pm 14 percent. As a percentage of total annual water use, median annual domestic water use for the selected cities ranged from 33 to 71 percent with an overall median of 57 percent.

Monthly production and water sales data were used to calculate daily per capita water use rates for the lowest 3 consecutive months (low-3) and the highest 3 consecutive months (high-3) of usage. Median low-3 domestic per capita water use for 16 selected cities ranged from 40 to 100 gpcd. Median high-3 domestic per capita water use for 16 selected cities ranged from 53 to 316 gpcd. In general, the median domestic water use as a percentage of the median total water use for 16 selected cities was similar for the low-3 and high-3 periods.

Statistical analyses of combined data for the selected cities indicated that none of the socioeconomic variables, including cost of water, were potentially useful as determinants of domestic water use at the national level. However, specific socioeconomic variables may be useful for the estimation of domestic water use at the State or local level. Different socioeconomic variables may be useful in different States. Statistical analyses indicated that specific climatic variables may be useful for the estimation of domestic water use for some, but not all, of the selected cities.

National average public supply per capita water use declined from 185 gpcd in 1990 to 171 gpcd in 2005. National average domestic delivery per capita water use declined from 105 gpcd in 1990 to 99 gpcd in 2005 . Average State domestic delivery per capita water use ranged from 51 to $189 \mathrm{gpcd}$ in 2005. The average annual total per capita water use in 19 selected cities that provided data for each year declined from 167 gpcd in 2006 to 145 gpcd in 2010. During this time period, average per capita water use measured during the low-3 period each year declined from 115 to $102 \mathrm{gpcd}$, and average per capita use measured during the high-3 period declined from 250 to 211 gpcd.

Continued collection of data on water deliveries to domestic populations, as well as updated estimates of the population served by these deliveries, is recommended for determination of regional and temporal trends in domestic per capita water use. Declines in various measures of per capita water use have been observed in recent years for several States with municipal water use data-collection programs.

Domestic self-supplied water use historically has not been metered. Estimates of self-supplied domestic water use are made using estimates of the population that is not served by public water suppliers and per capita coefficients. For 2005, the average State domestic self-supplied per capita use in the United States ranged from 50 to 206 gpcd. The median domestic self-supplied per capita use was 76 gpcd for States in which standard coefficients were used, and 98 gpcd for States in which coefficients were based on domestic deliveries from public supply.

In specific areas with scarce resources or increasing numbers of households with private wells, an assessment of domestic water use may require metering of households or development of more specific per capita coefficients to estimate water demand.

\section{Introduction}

In the United States in 2005, about 86 percent of the population obtained its domestic water from a public water supplier, whereas the other 14 percent of the population was self-supplied (Kenny and others, 2009). Domestic water use includes indoor and outdoor uses. Typical indoor uses include drinking, food preparation, washing clothes and dishes, and flushing toilets. Typical outdoor uses include watering lawns 
and gardens, and washing cars. Domestic self-supplied water is usually obtained from a private source such as a well, spring, or a cistern that stores rainwater or water hauled from another source. The U.S. Geological Survey's (USGS) National Water Use Information Program (NWUIP) publishes State estimates of public supply withdrawals, domestic deliveries from public water suppliers, and withdrawals for domestic self-supplied use. These estimates are published every 5 years through the USGS report series "Estimated use of water in the United States" (for example, see Kenny and others, 2009).

The availability and quality of water-use data varies considerably from State to State (National Research Council, 2002). For some categories of water use, the relation of water use to another measureable value can be expressed in terms of coefficients, and these coefficients can be used to estimate water use in the absence of direct measurements. Domestic water use is commonly related to population counts and expressed in terms of gallons per capita per day (gpcd). Gpcd coefficients can be determined using available records of metered sales to public-supplied populations. These coefficients can be used to estimate domestic deliveries to populations in areas without sales records, or to predict approximate future usage. Per capita coefficients are commonly used with estimates of self-supplied population to determine domestic self-supplied water use because this use is rarely metered. For some States, domestic self-supplied coefficients are derived from domestic delivery data, under the assumption that domestic self-supplied per capita use in a given area (for example, a county) is similar to that observed in the publicsupplied population. For other States, a uniform statewide per capita coefficient is used to estimate domestic self-supplied water use (Kenny and others, 2009).

A 3-year study by the USGS was begun in 2009 to document and interpret differences in domestic per capita water use among selected cities in various parts of the country in order to better evaluate coefficients used to estimate domestic water use and the methods used to develop those coefficients. Specific objectives of the study were to:

1. Describe domestic per capita water use for 21 selected U.S. cities for 2005-10;

2. Describe domestic per capita water use in the context of total water use for the selected cities;

3. Investigate socioeconomic and climatic variables that potentially affect domestic per capita water use for the selected cities;

4. Compare study results with per capita averages from published USGS estimates; and

5. Develop guidance for estimating domestic water use for USGS personnel and others that use NWUIP data.

\section{Purpose and Scope}

The purpose of this report is to present the results of the USGS study to describe recent domestic per capita water use in selected U.S. cities, investigate variables that potentially affect domestic water use, and provide guidance for estimating domestic water use. Study objectives were met by the collection and analysis of 2005-10 domestic water-use and related socioeconomic and climatic data for 21 selected U.S. cities. Methods and results presented in this report will provide guidance and perspective for USGS personnel and others using NWUIP data in studies involving domestic water use for individual communities or as a component of local, state, or national water-use assessments.

\section{Previous Studies}

Many studies have sought to quantify domestic water use in the United States. Common conclusions are that domestic water use varies considerably because of climate, socioeconomic factors, and customer habits. Outdoor per capita water use is larger in arid climates, and is more common at singlefamily dwellings than at multi-family dwellings. Indoor per capita water use is generally less in homes with greater numbers of occupants, unless those occupants tend to be at home during the day. Overall, water use is greater in dwellings with evaporative cooling systems (especially nonrecirculating ones) and those with older, high-volume fixtures or greater incidence of leaks (Vickers, 2001).

Domestic per capita water-use assessments rely on population counts and measures of water use ranging from physical recording of specific end uses at individual households to reported deliveries by individual cities and comparisons of aggregate use and populations in entire States. Several relevant studies are summarized here.

In the Residential End Uses of Water Study (REUWS) (Mayer and others, 1999), average domestic usage for a sample of 1,188 single-family households in 12 North American cities was 172 gpcd: indoor use averaged 69.3 gpcd, outdoor use $101 \mathrm{gpcd}$, and unidentified uses $1.7 \mathrm{gpcd}$. Mean daily per capita indoor water use among participating cities in the REUWS ranged from 57.1 to $83.5 \mathrm{gpcd}$, indicating that local and regional conditions affect indoor as well as outdoor use.

In a study of water use in the Seacoast region of southeastern New Hampshire (Horn and others, 2008), a domestic water-demand survey of households in 25 towns was used to determine that there was little difference in indoor water use between self-supplied houses and those receiving public water supplies. Subsequently, a per capita water-demand model was developed using metered delivery data from four water suppliers; the resulting estimate of mean domestic water use was 75 gpcd annually, 63 gpcd during the winter, and 92 gpcd in the summer. 
Per capita water use in 1990, 2000, and 2008 was examined in an analysis by the Pacific Institute of municipal deliveries to 100 cities and water agencies that use Colorado River Basin water (Cohen, 2011). Because municipal deliveries in that study included all uses except those for agricultural, energy, and mining, the per capita figures are larger than those for domestic use only and are more comparable to the total per capita uses presented herein. The Pacific Institute study determined that nearly all the water agencies included in the study experienced declines in per capita deliveries from 1990 to 2008. In some cases, less water was delivered in 2008 than in 1990 despite population growth in the service areas.

A residential water-use study, completed in 2009 by the Utah Division of Water Resources (DWRe), used information from randomly selected residents in 17 communities to determine average indoor and outdoor per capita water uses. In this study, indoor water use ranged from 51 to $74 \mathrm{gpcd}$, averaging 60 gpcd statewide based on average per household occupancy rates. This average was 14 percent less than the average statewide indoor use of 70 gpcd determined in an earlier Utah DWRe study (Utah Division of Water Resources, 2001, 2010). Indoor per capita use was less in homes built after the 1992 changes to the plumbing code and in households with greater numbers of people, and was larger in homes with floor space greater than 3,000 square feet and in homes with evaporative coolers. There was no substantial difference in indoor per capita use with respect to income level. Outdoor water use averaged 134 gpcd when averaged during 1 year, and varied greatly because of lawn sizes and availability of irrigation water from secondary sources. As was determined in the 1999 REUWS, outdoor water use was larger with automatic sprinkler systems than with manual sprinkler systems. The 2009 DWRe study also indicated lower indoor and outdoor water use in Salt Lake City homes that had heard of that city's "Slow the flow" media campaign to promote conservation.

Domestic water use and corresponding populations have been estimated for each State by USGS every 5 years since 1950. Estimates of domestic self-supplied water use in 2005 ranged from a State average of 50 gpcd in Kentucky to 206 gpcd in Nevada, with a national average of 89 gpcd. Estimates of domestic delivery water use ranged from a State average of 51 gpcd in Maine to 189 gpcd in Nevada, with a national average of 99 gpcd (Kenny and others, 2009). Estimation methods vary from State to State for the two types of domestic use (self-supplied and public-supplied), as discussed in the Guidance for Estimating Domestic Water Use section of this report.

\section{Methods}

The objectives of the study were accomplished through an analysis of water-use and related data that were collected for selected U.S. cities. The following sections provide an explanation of how the cities were selected, a description of the data collected, an explanation of calculations performed to derive additional data, and a description of statistical analyses completed.

\section{Selection of Cities}

Seven States in various geographic parts of the country were initially selected for the study. At the time the study was initiated, five of these States had agencies that do some type of annual water-use reporting for public water suppliers, whereas two did not. Water suppliers within each State were identified for possible inclusion in the study, and ultimately, 21 cities in 6 States were selected (fig. 1). These suppliers represented cities, towns, and villages, hereafter called cities. Cities with easily identified service areas and stable year-round populations were selected because computation of per capita averages depends on a reasonably accurate estimate of the population served. The availability of records for water production and ability to identify sales to single-family and multi-family homes for each year from 2005 to 2010 also were important selection criteria. Monthly water-production data were available for all cities. Annual sales data were used for cities without readily available monthly sales information, most notably for cities in Wisconsin. Annual reporting of water-use data to the California Division of Water Resources, the Kansas Department of Agriculture's Division of Water Resources, and the Wisconsin Public Service Commission facilitated the datacollection effort. Data requested directly from cities, without the benefit of a State reporting program, were more difficult to obtain.

\section{Description of Data Collected}

Data related to water use, population served, and water rates for the years 2005 through 2010 were obtained from several sources, including city clerks, water superintendents, and State agencies. Information on water withdrawals, purchases, and sales to other water suppliers was needed to establish the total (net) water use for a given city. Records of water sales to different customer classes (residential, commercial, industrial, and public uses) were needed to separate domestic use from the total. Domestic use was identified as sales to singlefamily and multi-family dwellings. Some residential sales data were reported separately for single-family and multi-family accounts; others were reported as a single total. The population served through retail sales to domestic users was reported by the cities annually or determined using census data if not reported. Numbers of residential service connections inside and outside city limits were helpful in adjusting the estimates of population served and evaluating changes in that estimate during the years 2005-10. Water rate structures in effect for residential customers during those years were obtained from the cities, their web sites, or State agencies that collect these data. 


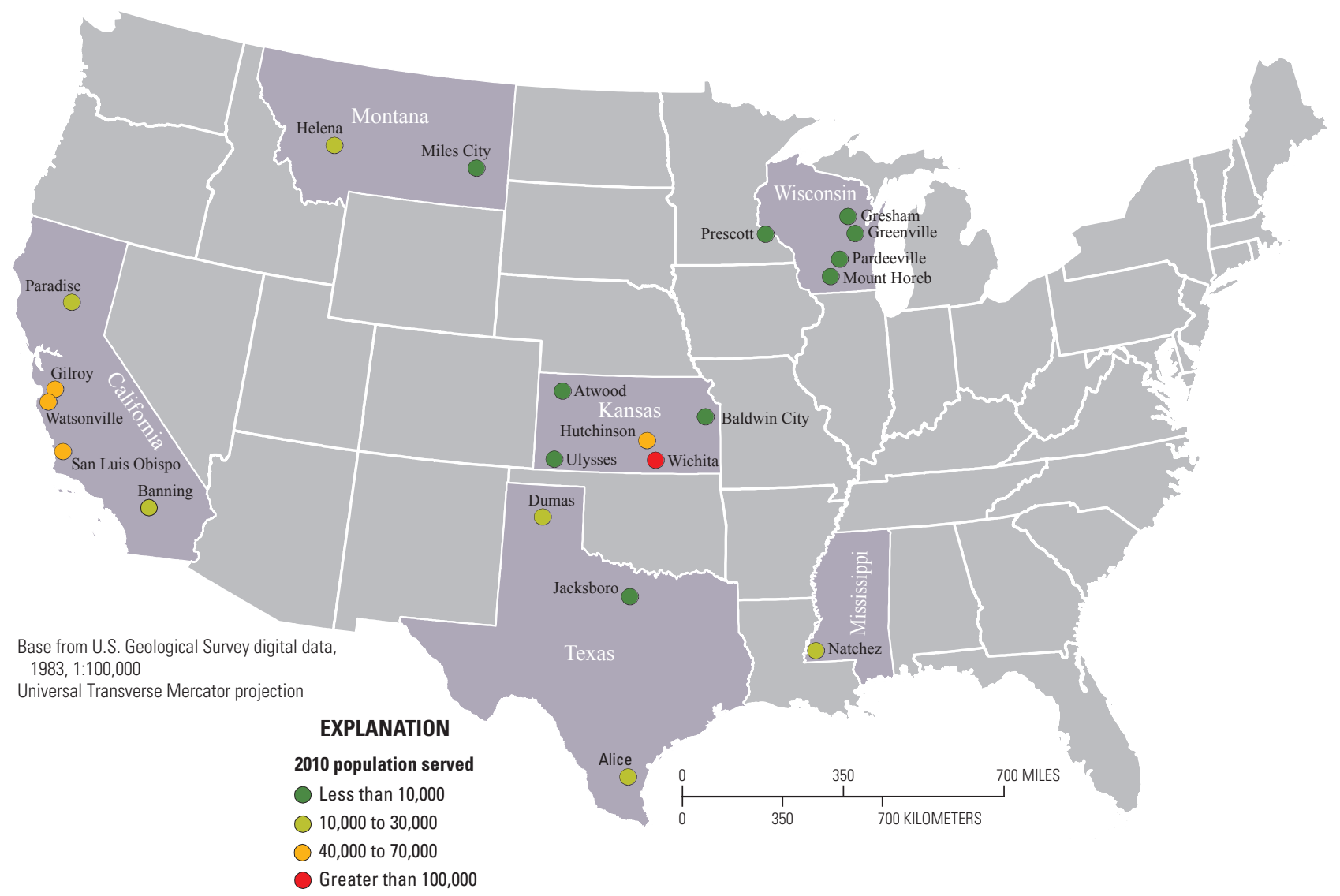

Figure 1. Location of, and 2010 population served for, selected U.S. cities included in study.

Demographic, economic, housing, and social (hereafter called socioeconomic) data for the selected cities were compiled using estimates released by the American Community Survey (ACS) (U.S. Census Bureau, 2010). The ACS was begun in 2005 to collect socioeconomic information formerly collected through the decennial census long form. In 2010, estimates based on ACS data collected during 2005-09 were released for all areas, including those with populations fewer than 20,000 people. Types of ACS data compiled were population and household age, house age, household income, household size, and family size.

Climatic data from weather stations in or near the selected cities (appendix 2) were compiled for 2005-10 (Weather Warehouse, 2011). Weather stations are operated by agencies within the National Oceanic and Atmospheric Administration (NOAA). Data used for the study included monthly precipitation and mean monthly maximum temperature. Weather stations chosen for the selected cities had missing data for 17 of 1,512 observations of monthly maximum temperatures and 17 of 1,512 observations of monthly precipitation. Values from a nearby station were substituted to complete the record for Dumas, Tex. Long-term average values were used to complete the record for Gilroy, Calif., and Jacksboro, Tex.

\section{Data Calculations}

Monthly water withdrawal and sales data from the selected cities were received in various units of measurement, including acre-feet, cubic feet, and various multipliers of gallons. These units were standardized in order to calculate usage in gpcd. Several types of per capita averages were calculated, using the estimated population served and different quantities of water for varying time intervals, as described below.

"Total" water use was defined as the net use by each city after sales to other water suppliers were subtracted from total production, which included withdrawals from their own sources plus purchases from other water suppliers. For several cities in California, sales to agricultural uses also were subtracted. Thus, the total use represents water that was used for customers, as well as water used for public services and system losses, within the city's own service area. Total use by a public water supplier, as defined here, is comparable to the definition of public supply water use used by the NWUIP (Kenny and others, 2009).

"Domestic" water use was defined as water sold to customers at single-family and multi-family residences for indoor and outdoor uses. It was not possible to compute separate gpcd values for each type of housing without knowing the population at each; therefore, the gpcd represents an average for the 
population. Residences outside city limits that are within a city's service area were included, and the number of residents at these locations was estimated using average numbers of persons per connection.

"Low-3" gpcd was defined as the per capita average for the 3 consecutive months of lowest usage within a given year. "High-3" gpcd was defined as the per capita average for the 3 consecutive months of highest usage within a given year. Low-3 and high-3 total gpcd were calculated for all cities because monthly production data were available. Low-3 and high-3 domestic gpcd were calculated only for cities that provided monthly sales data. Three-month intervals (set to 90 days for calculations) were chosen for the low- 3 and high-3 gpcd averages because reported monthly data do not always represent discrete months because of varied meter reading cycles. With sales data in particular, the calendar month cannot always be identified because sales may be reported for the month following the actual usage, or may be a composite of months because of continuous meter reading cycles.

Total water use for each city was split into three subcategories of use to enable comparative analyses. "Domestic" use included sales to single-family and multi-family dwellings. "Commercial and industrial" uses were combined into one category because of differences in how each of these customer categories may be defined from one city to the next, and because reported industrial sales, if any, were relatively small in the selected cities. The category "other" included all other uses, metered and unmetered. Other uses include water treatment; public uses such as city buildings, parks, pools, and golf courses; public services such as firefighting and streetwashing; maintenance such as line flushing; and distribution-system losses.

Water rates that apply to residential customers were calculated for various levels of monthly water usage. Rates for one system with bimonthly billing and one system with quarterly billing were adjusted accordingly. Rates for water billed in units of hundred cubic feet were calculated for equivalent volumes in units of thousand gallons.

Monthly climatic data were summed or averaged to provide annual climatic data for each of the selected cities for 2005 through 2010. Monthly precipitation was totaled to determine annual precipitation for each year. The average monthly maximum temperature was used to determine the annual mean of monthly mean maximum temperatures (hereafter annual maximum temperature), and the May-September mean of monthly mean maximum temperatures (hereafter May-September maximum temperature).

\section{Statistical Analyses}

Statistical analyses were used to investigate variables that potentially affect, and may be helpful in the estimation of, domestic water use. For this purpose, the coefficient of determination $\left(R^{2}\right)$ was computed to assess the linear relation
Table 1. Water-use, socioeconomic, and climatic variables used in statistical analyses.

\section{Water-use variables}

Median annual average domestic per capita water use.

Annual mean domestic per capita water use.

Annual low-3 domestic per capita water use.

Annual high-3 domestic per capita water use.

Socioeconomic variables

Median monthly cost for 10,000 gallons of water.

Median age of population.

Percentage of population age 18 and over.

Percentage of population age 65 and over.

Percentage of houses built 1939 or earlier.

Percentage of houses built 1940 to 1979.

Percentage of houses built 1980 to 1989.

Percentage of houses built 1990 and after.

Percentage of households earning less than $\$ 35,000$ per year.

Percentage of households earning $\$ 35,000$ to $\$ 50,000$ per year.

Percentage of households earning $\$ 50,000$ to $\$ 100,000$ per year.

Percentage of households earning $\$ 100,000$ to $\$ 200,000$ per year.

Percentage of households earning more than $\$ 200,000$ per year.

Median annual household income (dollars).

Percentage of households with one or more people under age 18.

Percentage of households with one or more people age 65 and over.

Average household size (persons per household).

Average family size (persons per family).

Climatic variables

Annual precipitation.

Annual maximum temperature ${ }^{1}$.

May-September maximum temperature ${ }^{2}$.

${ }^{1}$ Computed as the mean of monthly mean maximum temperatures.

${ }^{2}$ Computed as the mean of monthly mean maximum temperatures for May-September.

between domestic water use and individual socioeconomic and climatic variables (table 1). $R^{2}$ is the fraction of the variance explained by a regression model (Helsel and Hirsch, 1992) and provides an indication of the "goodness of fit," or its ability to accurately model a data set. Generally, the larger the $R^{2}$ (up to a maximum possible value of 1.0) the more reliable is the model. For this report, an $R^{2}$ of 0.6 or greater was interpreted to indicate a possible relation between variables.

To investigate socioeconomic variables that potentially affect domestic water use, data for 20 of the 21 selected cities were used in a combined assessment that included all the cities in a single data set. Socioeconomic data were not available for Greenville, Wis. The dependent variable used in these analyses was the median of the annual average domestic per 
capita water use observed for each city from 2005 to 2010. Independent variables used included the median monthly cost for 10,000 gallons of water for each city from 2005 to 2010, as well as an additional 17 socioeconomic variables that describe population and household age, house age, household income, household size, and family size (table 1).

To investigate climatic variables that potentially affect domestic water use, data for all 21 selected cities were used in a city-by-city assessment. Three analyses were completed that used data for each year from 2005 to 2010. In the first analysis, the dependent variable used was the annual mean domestic per capita water use. In the second analysis, the dependent variable used was the annual low-3 domestic per capita water use. In the third analysis, the dependent variable used was the annual high-3 domestic per capita water use. Independent variables used in all three analyses were annual precipitation, annual maximum temperature, and May-September maximum temperature. Only cities with complete domestic per capita water use and climatic data for at least 5 of the 6 years were included in each analysis. For the first analysis, all 21 cities were included. For the second and third analyses, only 15 cities were included because monthly water sales data were incomplete or unavailable for Jacksboro, Tex., Greenville, Wis., Gresham, Wis., Mount Horeb, Wis., Pardeeville, Wis., and Prescott, Wis.

\section{Description of Domestic Per Capita Water Use for Selected U.S. Cities}

\section{Average Annual Domestic and Total Per Capita Water Use}

Domestic per capita water use from 2005 to 2010 for the 21 selected cities ranged from a median annual average of 43 gpcd (Gresham, Wis.) to 177 gpcd (Paradise, Calif.) (fig. $2 A$, appendix1). Among the States with data for three or more cities, median annual average domestic per capita water use was the most variable for Kansas (five cities) with a range of 45 to 159 gpcd. For California (five cities) and Texas (three cities), the respective ranges were 72 to 177 and 70 to 123 gpcd. Wisconsin (five cities) was the least variable with a range of 43 to 62 gpcd (fig. $2 A$ ). On average, domestic per capita water use in Wisconsin's cities was the lowest among the States sampled. In terms of year-to-year variability, the difference from the median ranged from \pm 7 percent (Watsonville, Calif.) to \pm 26 percent (Jacksboro, Tex.). Overall, the median year-to-year variability was \pm 14 percent. In addition to the median, figure $2 A$ shows the range in annual average domestic per capita water use for 2005 to 2010 for each of the selected cities.

Total per capita water use from 2005 to 2010 for the 21 cities ranged from a median annual average of $78 \mathrm{gpcd}$ (Pardeeville and Gresham, Wis.) to 294 gpcd (Banning, Calif.) (appendix 1). Total per capita water use from 2005 to 2010, and the part each year that was domestic, is shown in figure $2 B$ for cities with median domestic gpcd of 100 or more. Total and domestic gpcd for cities with median domestic gpcd between 65 and 100 are shown in figure $2 C$. For cities with median domestic gpcd of 65 or less, total and domestic gped are shown in figure $2 D$.

Domestic water use as a percentage of total use varied by city (figs. $2 B-2 D$, appendix 1 ). In general, the percentage of total use that is domestic was larger in smaller cities that have less commercial and industrial activity, and in cities with relatively small amounts of water that were used for public services or unaccounted for.

As a percentage of total annual water use, median annual domestic water use ranged from 33 percent (Natchez, Miss.) to 71 percent (Paradise, Calif.) with an overall median of 57 percent (fig. 3, appendix1). Among the States with data for three or more cities, Texas was the most variable with a range of 34 to 64 percent followed by Kansas with a range of 42 to 65 percent. California and Wisconsin were the least variable with respective ranges of 55 to 71 and 50 to 68 percent. In terms of year-to-year variability, the difference from the median ranged from \pm 2 percent (Banning, Calif.) to \pm 30 percent (Natchez, Miss., and Jacksboro, Tex.). Overall, the median year-to-year variability was \pm 12 percent.

\section{Seasonal Domestic Per Capita Water Use}

Low-3 and high-3 domestic per capita water use were calculated for the 16 cities for which monthly domestic water sales data were available. For Alice, Tex., monthly sales data were only available for 2005 to 2009, and for Greenville, Wis., the data were only available for 2007 to 2010 . Monthly sales data were not available for Jacksboro, Tex., Gresham, Wis., Mount Horeb, Wis., Pardeeville, Wis., and Prescott, Wis.

Seasonal differences in domestic water use were observed for the 16 cities for which monthly data were available. The lowest domestic per capita use observed during any 3 consecutive months was indicative of a period during the year when outdoor water use was at a minimum. The highest domestic per capita use observed during any 3 consecutive months was indicative of a period when outdoor water use was at a maximum. The extent to which domestic use increases because of outdoor water uses was illustrated by a comparison between the median low-3 and median high-3 domestic per capita use for each city (fig. $4 A$ ).

Median low-3 domestic per capita water use ranged from 40 gpcd (Baldwin City, Kans.) to 100 gpcd (Banning, Calif.) (fig. $4 A$ ). In all but two cities, the median low-3 use was less than 80 gpcd. In Paradise ( 83 gpcd) and Banning, Calif. (100 gpcd), the higher median low-3 use may indicate that some outdoor water use occurs year-round. Year-to-year low-3 variability, as indicated by the difference from the median, ranged from \pm 9 percent (Watsonville, Calif., and Hutchinson, Kans.) to \pm 30 percent (Helena, Mont.) with an overall median of \pm 13 percent. 

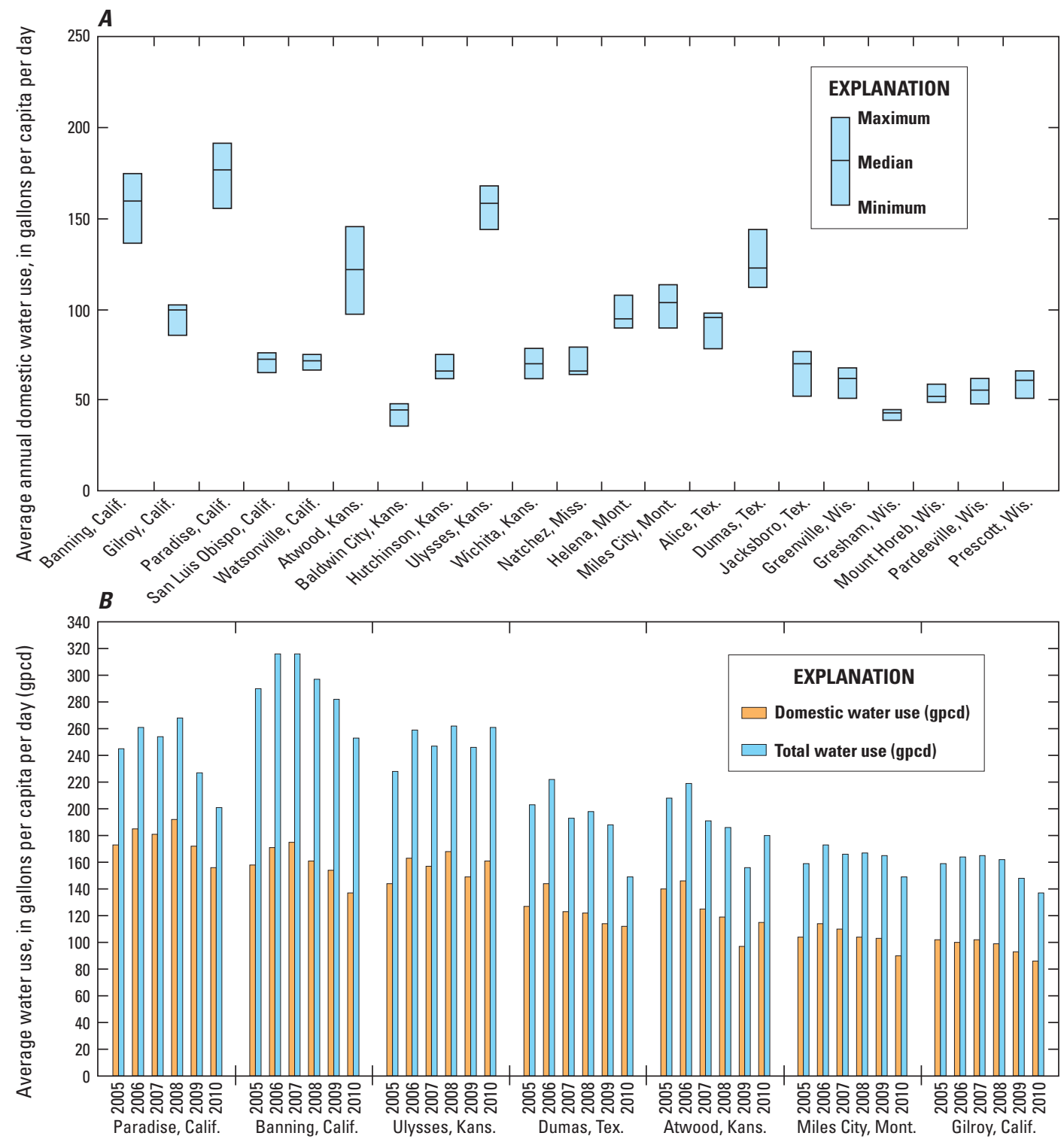

Figure 2. (A) minimum, median, and maximum domestic per capita water use for selected U.S. cities, 2005-10, (B) total and domestic per capita water use for selected U.S. cities with median domestic use of 100 gallons per capita per day or more, 2005-10, $(C)$ total and domestic per capita water use for selected U.S. cities with median domestic use between 65 and 100 gallons per capita per day, 2005-10, and $(D)$ total and domestic per capita water use for selected U.S. cities with median domestic use of less than 65 gallons per capita per day, 2005-10.

Median high-3 domestic per capita water use ranged from 53 gpcd (Baldwin City, Kans.) to 316 gpcd (Paradise, Calif.). Year-to-year high-3 variability, as indicated by the difference from the median, ranged from \pm 9 percent (Paradise and San Luis Obispo, Calif.) to \pm 30 percent (Atwood, Kans.) with an overall median of \pm 17 percent. The amount by which median high-3 exceeded median low-3 domestic water use ranged from 28 percent (Natchez, Miss.) to 281 percent (Paradise, Calif.) with an overall median of 110 percent (fig. 4A, appendix1). This is an indication of the magnitude of difference in seasonal domestic per capita water use. Cities with a small difference between low-3 and high-3 domestic usage (for example, Natchez, Miss., Baldwin City, Kans., San Luis Obispo, Calif., and Greenville, Wis.) have more constant monthly water use than cities with large differences (for example, Helena, Mont., Miles City, Mont., Ulysses, Kans., and Paradise, Calif.).

Year-to-year variability in seasonal domestic per capita water use is illustrated in figure $4 B$ for cities with more than a 100 gpcd average difference between low-3 and high-3 use, and in figure $4 C$ for cities with less than a 100 gpcd average difference between low-3 and high-3 use. In general, during the 6-year study period (2005-10), high-3 domestic gpcd typically decreased whereas low-3 domestic gpcd was relatively 


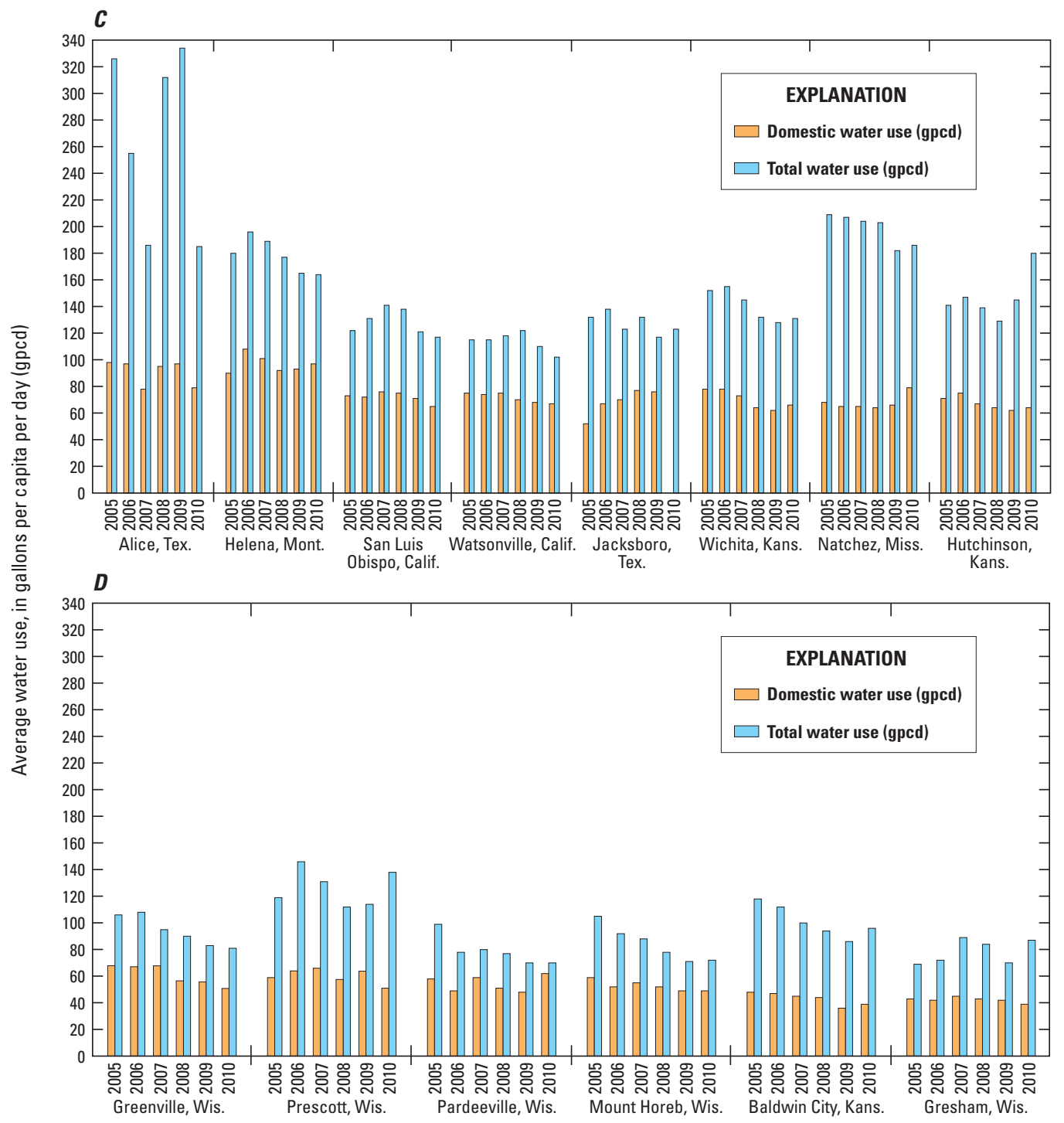

Figure 2. (A) minimum, median, and maximum domestic per capita water use for selected U.S. cities, 2005-10, (B) total and domestic per capita water use for selected U.S. cities with median domestic use of 100 gallons per capita per day or more, 2005-10, (C) total and domestic per capita water use for selected U.S. cities with median domestic use between 65 and 100 gallons per capita per day, 2005-10, and $(D)$ total and domestic per capita water use for selected U.S. cities with median domestic use of less than 65 gallons per capita per day, 2005-10.-Continued

more consistent (figs. 4B, 4C). Larger per-capita values for 2010 in Natchez, Miss., resulted from a decrease in the census population figure used that year compared to previous years.

In general, the median domestic water use as a percentage of the median total water use was similar for the low-3 and high-3 periods. Median low- 3 domestic water use as a percentage of median low-3 total water use ranged from 32 percent (Natchez, Miss.) to 66 percent (Gilroy, Calif.) with an overall median of 57 percent (fig. $5 A$, appendix 1). Median high-3 domestic water use as a percentage of median high-3 total water use ranged from 31 percent (Alice, Tex.) to 75 percent (Paradise, Calif.) with an overall median of 58 percent (fig. $5 B$, appendix 1 ).

\section{Variables That Potentially Affect Domestic Water Use}

As a calculated value, domestic per capita water use can be affected by numerous factors, mainly the accuracy of measured water pumped and metered water usage, the accuracy of the population count, and the extent to which the water use and population reflect the time period considered. For this study, cities were selected with the assumption that volumes of water pumped and purchased were measured accurately, that water sales to single-family and multi-family dwellings were accurately metered and adequately separated from commercial 


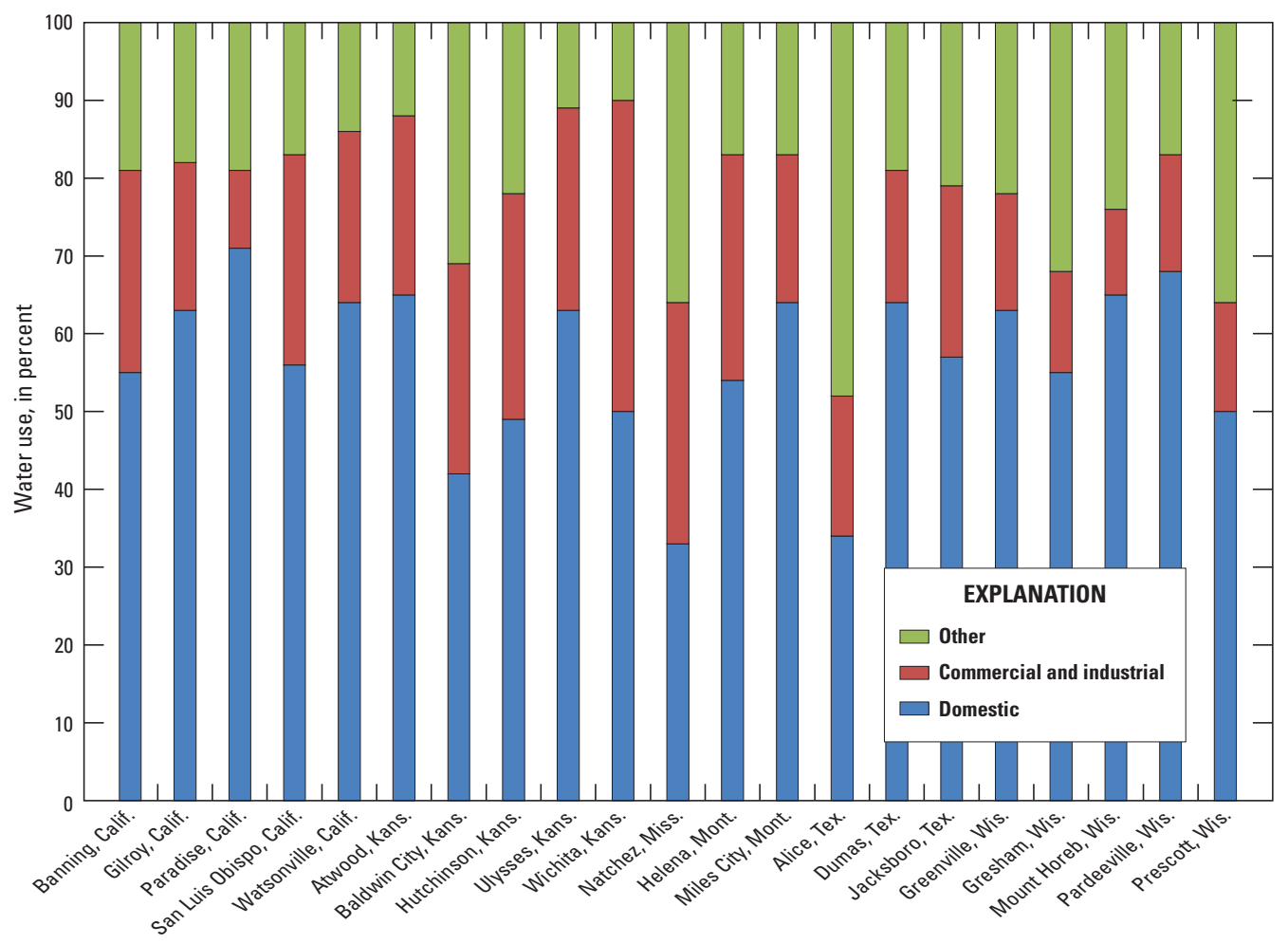

Figure 3. Median domestic, commercial and industrial, and other water use as percentages of total annual water use for selected U.S. cities, 2005-10.

Table 2. Coefficients of determination $\left(R^{2}\right)$ for median annual average domestic per capita water use compared to 18 socioeconomic variables for 20 selected U.S. cities, five selected California cities, and five selected Kansas cities, 2005-10.

[n, number of samples; shading, $R^{2}$ value of 0.6 or greater; ( ), inverse relation]

\begin{tabular}{|c|c|c|c|}
\hline \multirow{2}{*}{ Socioeconomic variable } & \multicolumn{3}{|c|}{ Coefficient of determination $\left(R^{2}\right)$} \\
\hline & National (n=20) & California (n=5) & Kansas $(n=5)$ \\
\hline Median monthly cost for 10,000 gallons of water & 0.11 & 0.07 & 0.35 \\
\hline Median age of population & .31 & .97 & .40 \\
\hline Percentage of population age 18 and over & 0 & .06 & .19 \\
\hline Percentage of population age 65 and over & .23 & .97 & .07 \\
\hline Percentage of houses built 1939 or earlier & .22 & $(.72)$ & .03 \\
\hline Percentage of houses built 1940 to 1979 & .17 & .06 & .67 \\
\hline Percentage of houses built 1980 to 1989 & .06 & .28 & .13 \\
\hline Percentage of houses built 1990 and after & .03 & 0 & .20 \\
\hline Percentage of households earning less than $\$ 35,000$ per year & .06 & .07 & .10 \\
\hline Percentage of households earning $\$ 35,000$ to $\$ 50,000$ per year & .03 & .17 & .36 \\
\hline Percentage of households earning $\$ 50,000$ to $\$ 100,000$ per year & .10 & .04 & .01 \\
\hline Percentage of households earning $\$ 100,000$ to $\$ 200,000$ per year & .02 & .05 & .26 \\
\hline Percentage of households earning more than $\$ 200,000$ per year & .01 & .11 & .15 \\
\hline Median annual household income (dollars) & .07 & .05 & .12 \\
\hline Percentage of households with one or more people under age 18 & .02 & .14 & .01 \\
\hline Percentage of households with one or more people age 65 and over & .08 & .89 & .01 \\
\hline Average household size (persons per household) & .01 & .26 & .06 \\
\hline Average family size (persons per family) & .01 & .21 & 0 \\
\hline
\end{tabular}



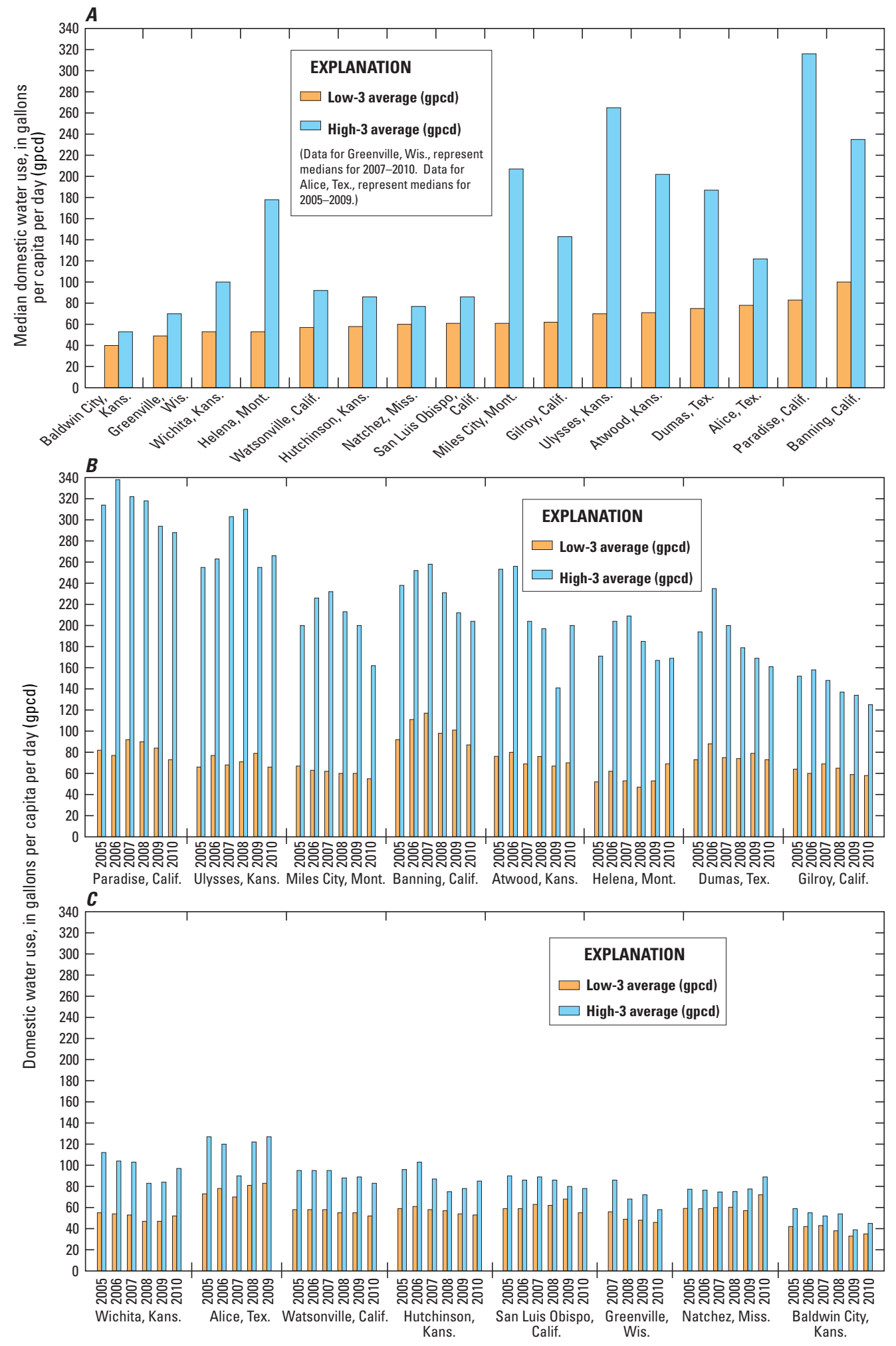

Figure 4. $(A)$ median domestic per capita water use for lowest and highest consecutive 3-month periods for selected U.S. cities, 2005-10, (B) domestic per capita water use for selected U.S. cities with average difference between lowest and highest consecutive 3-month periods of more than 100 gallons per capita per day, 2005-10, and $(C)$ domestic per capita water use for selected U.S. cities with average difference between lowest and highest consecutive 3-month periods of less than 100 gallons per capita per day, 2005-10. 


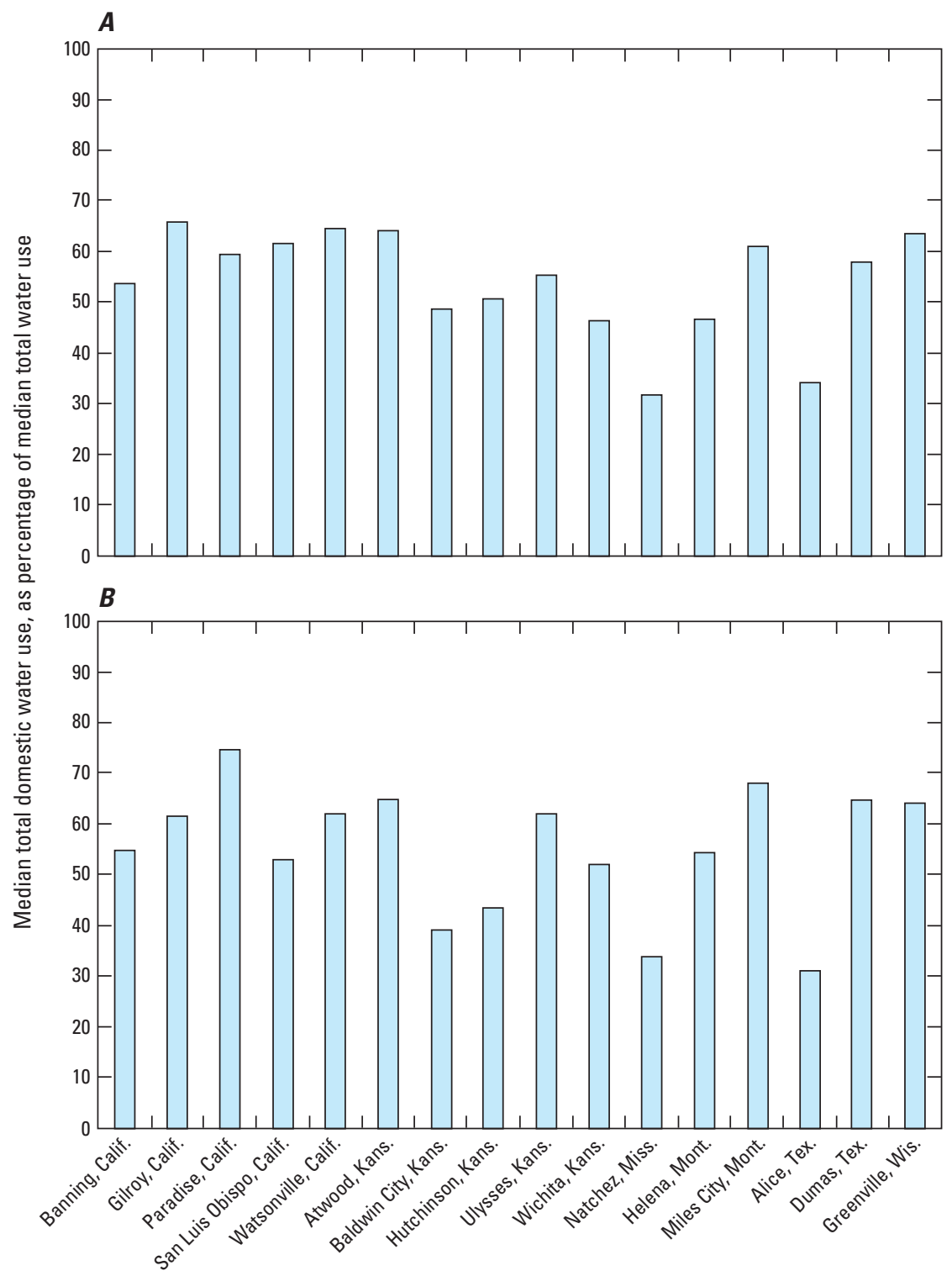

Figure 5. (A) median domestic water use as percentage of median total water use for lowest consecutive 3-month periods for selected U.S. cities, 2005-10, and (B) median domestic water use as percentage of median total water use for highest consecutive 3-month periods for selected U.S. cities, 2005-10.

uses, and that the year-round resident population served could be approximated using information on service connections and census data. The calculated domestic gpcd estimates provided the dependent variables with which to investigate the possible effects of the independent socioeconomic and climatic variables.

\section{Socioeconomic Variables}

In the combined assessment, which used socioeconomic data for 20 cities, statistical analyses indicated that none of the socioeconomic variables considered were potentially useful as determinants of domestic water use. $R^{2}$ values were small, ranging from 0 to 0.31 (table 2).
However, in State assessments for California and Kansas, each of which used data for five cities, potentially useful variables were identified. For California, a direct relation was indicated between median annual average domestic water use and median age $\left(R^{2}=0.97\right)$, percentage of population age 65 and over $\left(R^{2}=0.97\right)$, and percentage of households with one or more people age 65 or over $\left(R^{2}=0.89\right)$ (figs. $6 A-6 C$, table 2). An inverse relation was indicated between median annual average domestic water use and percentage of houses built in 1939 or earlier $\left(R^{2}=0.72\right)$ (fig. $6 D$, table 2$)$. For Kansas, a direct relation was indicated between median annual average domestic water use and percentage of houses built 1940 to $1979\left(R^{2}=0.67\right)$ (fig. 7, table 2). 

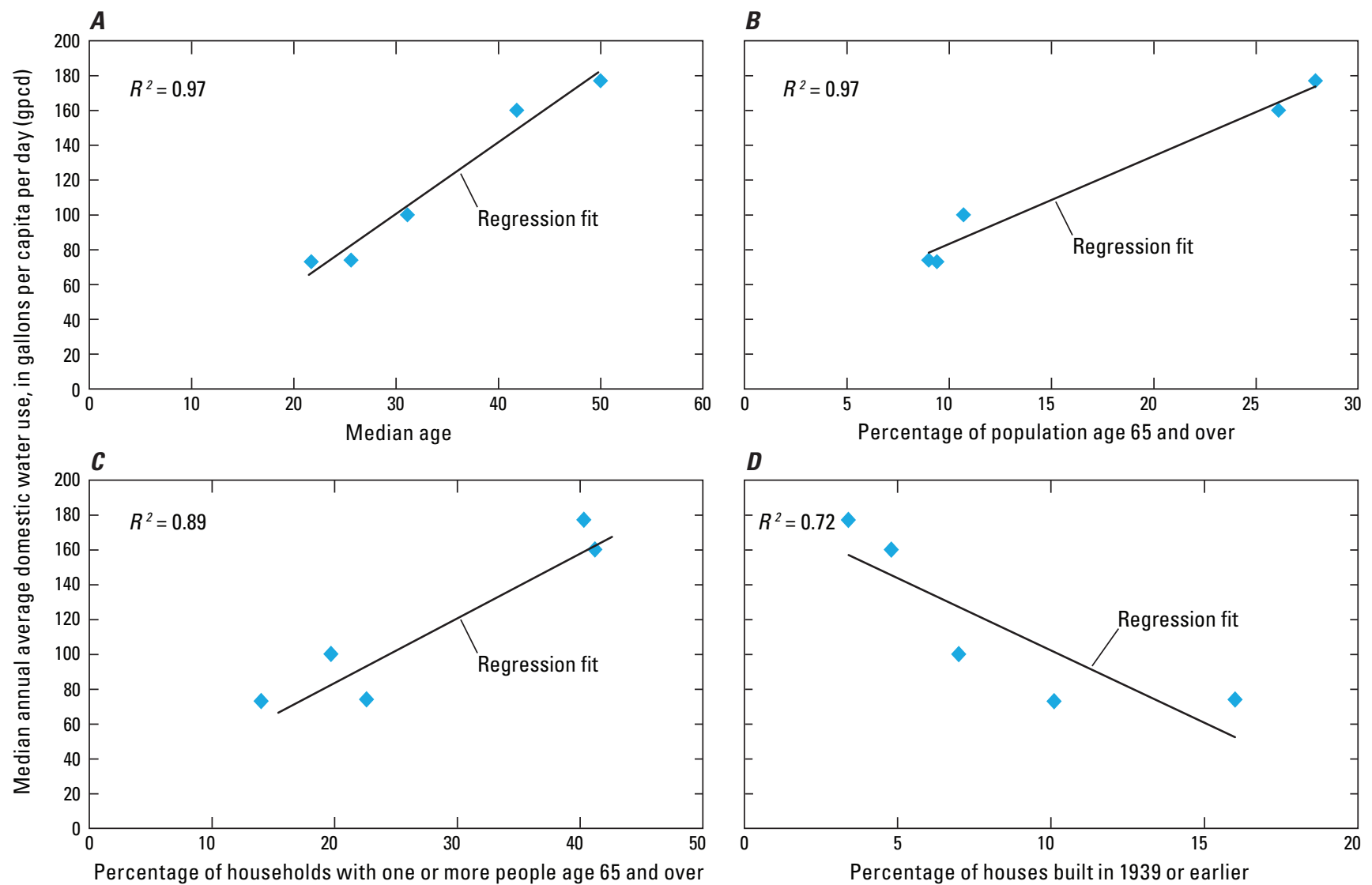

Figure 6. Relation and coefficient of determination $\left(R^{2}\right)$ between median annual average domestic per capita water use and $(A)$ median age, $(B)$ percentage of population age 65 and over, $(C)$ percentage of households with one or more people age 65 and over, and $(D)$ percentage of houses built in 1939 or earlier for five selected cities in California, 2005-10.

Because the two State assessments only included data for five cities, the indicated relations between domestic water use and socioeconomic variables may not be meaningful. Nevertheless, the results of the State assessments are worth noting for two reasons. First, it was demonstrated that specific socioeconomic variables, despite not being of apparent utility for estimating domestic water use at the national level, may be useful for the estimation of domestic water use at the State or local level. Second, it was demonstrated that different socioeconomic variables may be useful in different States.

The average monthly cost of water and the percentage water rate increase in cost during the 6 years (2005-10) was not necessarily related to domestic per capita use. Cities with the largest domestic per capita use included those with the lowest water rates (Dumas, Tex., Ulysses, Kans., and Gilroy, Calif.) but also some with large percentage water rate increases (Atwood, Kans., and Miles City, Mont.). Some of the cities with moderate or low per capita uses (Baldwin City, Kans., Gresham, Wis., San Luis Obispo, Calif., and Jacksboro, Tex.) had the largest average costs for water and often large percentage increases in water rates; however, other cities with low per capita use, such as Greenville, Wis., Prescott, Wis., and Pardeeville, Wis., had low costs for water. These Wisconsin cities each utilize groundwater, which generally is less costly to treat than surface water.

\section{Climatic Variables}

The city-by-city assessment indicated that the importance of climatic variables as possible determinants of domestic water use was city-specific. For the relation between annual mean domestic water use and annual precipitation, the $R^{2}$ values ranged from 0 (Natchez, Miss., and Pardeeville, Wis.) to 0.84 (Gresham, Wis.). In addition to Gresham, Wis. (fig. 8), other cities with an $R^{2}$ of at least 0.60 were San Luis Obispo, Calif., Miles City, Mont., Alice, Tex., Jacksboro, Tex., and Greenville, Wis. (table 3). With one exception, the relation for these six cities was inverse. That is, annual mean domestic water use decreased as annual precipitation increased. The exception was Jacksboro, Tex., for which annual mean domestic water use increased as annual precipitation increased (fig. 9). This unexpected result may, in part, be a result of the limited number of years of data used in the analysis.

Likewise, the relation between annual mean domestic water use and temperature was city-specific. For the relation between annual mean domestic water use and annual maximum temperature, the $R^{2}$ values ranged from 0 (Prescott, Wis.) to 0.87 (Miles City, Mont.). In addition to Miles City, Mont. (fig. $10 A$ ), other cities with an $R^{2}$ of at least 0.60 were Gilroy, Calif., Paradise, Calif., Atwood, Kans., and Alice, Tex. 


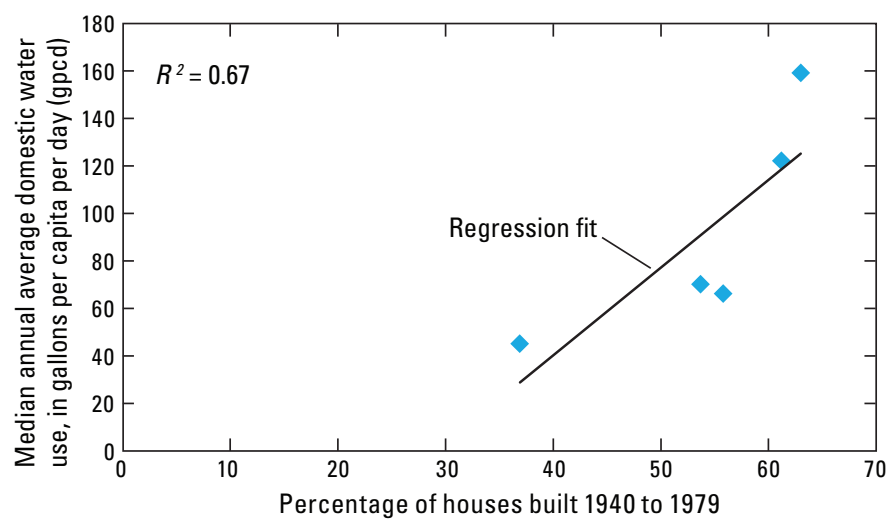

Figure 7. Relation and coefficient of determination $\left(R^{2}\right)$ between median annual average domestic per capita water use and percentage of houses built 1940 to 1979 for five selected cities in Kansas, 2005-10.

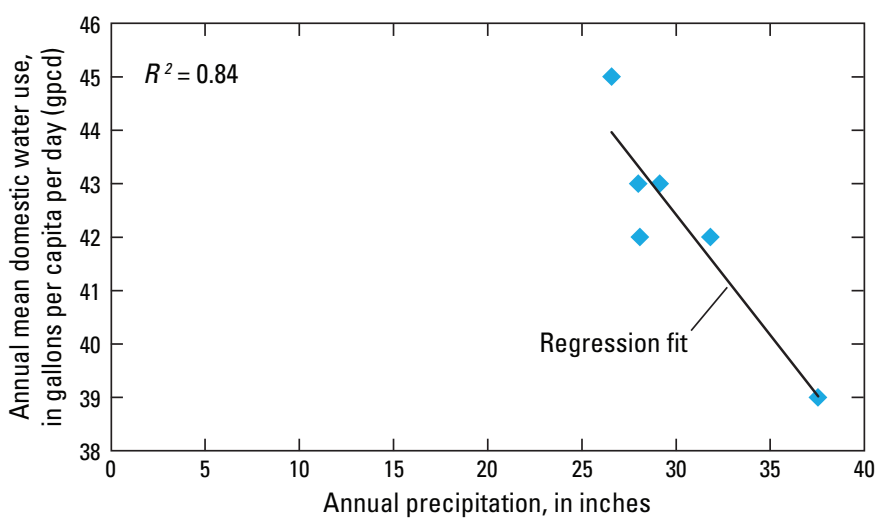

Figure 8. Relation and coefficient of determination $\left(R^{2}\right)$ between annual mean domestic per capita water use and annual precipitation for Gresham, Wisconsin, 2005-10.

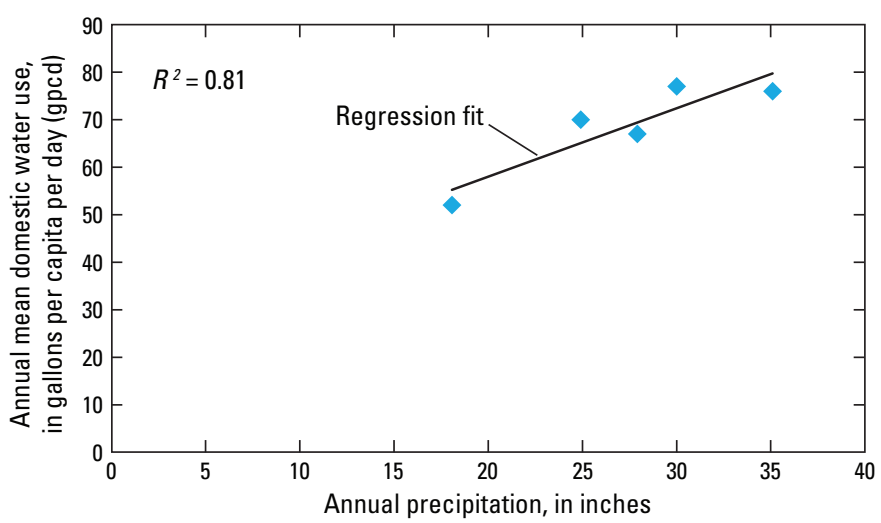

Figure 9. Relation and coefficient of determination $\left(R^{2}\right)$ between annual mean domestic per capita water use and annual precipitation for Jacksboro, Texas, 2005-10.

(table 3). A direct relation was indicated for these five cities in which annual mean domestic water use increased as annual maximum temperature increased. For the relation between annual mean domestic water use and May-September
Table 3. Coefficients of determination $\left(R^{2}\right)$ for annual mean domestic per capita water use compared to three climatic variables for 21 selected U.S. cities, 2005-10.

[shading, $R^{2}$ value of 0.6 or greater; ( ), inverse relation]

\begin{tabular}{|c|c|c|c|}
\hline \multirow[b]{2}{*}{ City (fig. 1) } & \multicolumn{3}{|c|}{ Coefficients of determination $\left(R^{2}\right)$} \\
\hline & $\begin{array}{c}\text { Annual } \\
\text { precipita- } \\
\text { tion }\end{array}$ & $\begin{array}{c}\text { Annual } \\
\text { maximum } \\
\text { tempera- } \\
\text { ture }^{1}\end{array}$ & $\begin{array}{c}\text { May- } \\
\text { September } \\
\text { maximum } \\
\text { tempera- } \\
\text { ture }^{2}\end{array}$ \\
\hline Banning, Calif. & 0.50 & 0.31 & 0.07 \\
\hline Gilroy, Calif. & .22 & .69 & .34 \\
\hline Paradise, Calif. & .48 & .65 & .57 \\
\hline San Luis Obispo, Calif. & $(.78)$ & .22 & .10 \\
\hline Watsonville, Calif. & .10 & .08 & .02 \\
\hline Atwood, Kans. & .03 & .69 & .75 \\
\hline Baldwin City, Kans. & .49 & .43 & .33 \\
\hline Hutchinson, Kans. & .10 & .46 & .05 \\
\hline Ulysses, Kans. & .20 & .08 & .21 \\
\hline Wichita, Kans. & .16 & .50 & .26 \\
\hline Natchez, Miss. & 0 & .18 & .62 \\
\hline Helena, Mont. & .13 & .43 & .23 \\
\hline Miles City, Mont. & $(.64)$ & .87 & .87 \\
\hline Alice, Tex. & $(.82)$ & .85 & .60 \\
\hline Dumas, Tex. & .07 & .38 & .07 \\
\hline Jacksboro, Tex. & .81 & .09 & .03 \\
\hline Greenville, Wis. & $(.69)$ & .02 & .19 \\
\hline Gresham, Wis. & $(.84)$ & .08 & .42 \\
\hline Mount Horeb, Wis. & .16 & .19 & .48 \\
\hline Pardeeville, Wis. & 0 & .43 & .67 \\
\hline Prescott, Wis. & .48 & 0 & .14 \\
\hline
\end{tabular}

maximum temperature, the $R^{2}$ values ranged from 0.02 (Watsonville, Calif.) to 0.87 (Miles City, Mont.). In addition to Miles City, Mont. (fig. 10B), other cities with an $R^{2}$ of at least 0.60 were Atwood, Kans., Natchez, Miss., Alice, Tex., and Pardeeville, Wis. A direct relation was indicated for these five cities in which annual mean domestic water use increased as May-September maximum temperature increased. For several of the cities, the strength of the relation between annual mean domestic water use and annual maximum temperature, as compared to the strength of the relation between annual mean domestic water use and May-September maximum temperature, was dissimilar (table 3). 

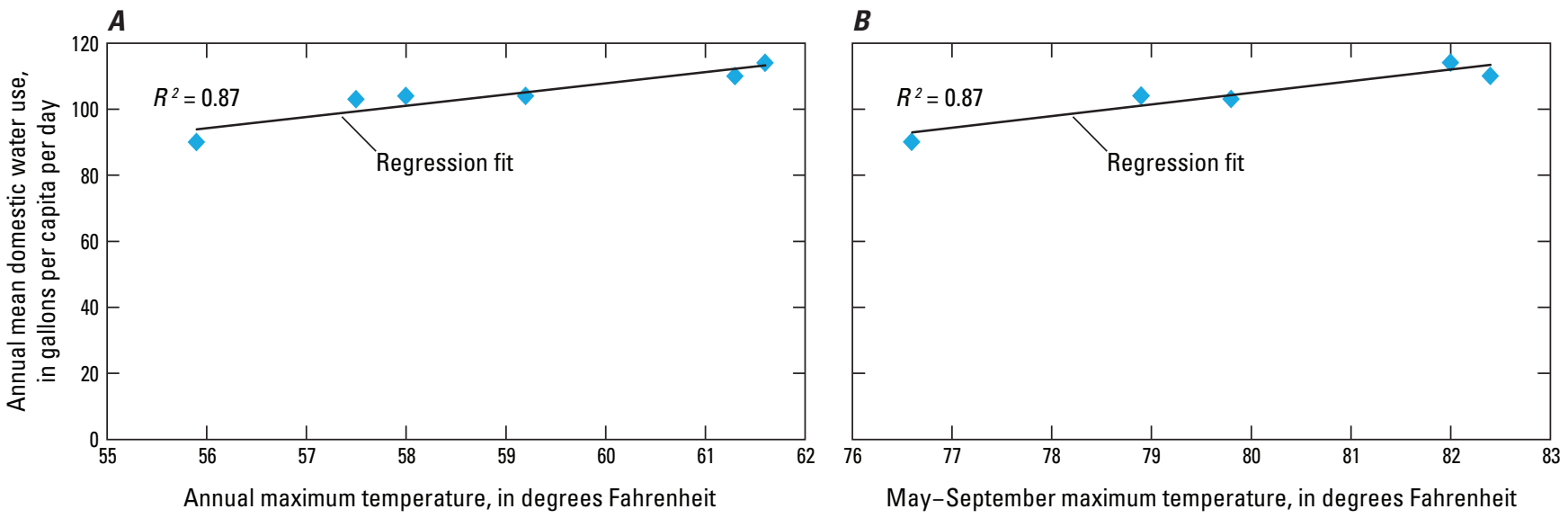

Figure 10. Relation and coefficient of determination $\left(R^{2}\right)$ between annual mean domestic per capita water use and $(A)$ annual maximum temperature, and (B) May-September maximum temperature for Miles City, Montana, 2005-10.

The importance of climatic variables as possible determinants of low- 3 and high- 3 domestic water use also was city-specific. For the relation between low-3 domestic water use and annual precipitation, the $R^{2}$ values ranged from 0 (Atwood, Kans., Hutchinson, Kans., and Natchez, Miss.) to 0.80 (Paradise, Calif.). In addition to Paradise, Calif., other cities with an $R^{2}$ of at least 0.60 were Banning, Calif., Ulysses, Kans., Helena, Mont., and Alice, Tex. (table 4). An inverse relation was indicated for Banning, Calif., Paradise, Calif., and Alice, Tex., in which low-3 domestic water use increased as annual precipitation decreased. However, for Ulysses, Kans., and Helena, Mont., a direct relation was indicated in which low-3 domestic water use increased as annual precipitation increased.

The relation between low-3 domestic water use and annual maximum temperature, as evidenced by the $R^{2}$ values, ranged from 0 (Ulysses, Kans.) to 0.88 (San Luis Obispo, Calif.). Besides San Luis Obispo, Calif., other cities with an $R^{2}$ of at least 0.60 were Paradise, Calif., Alice, Tex., and Dumas, Tex. (table 4). For these four cities, a direct relation was indicated in which low-3 domestic water use increased as annual maximum temperature increased. The relation between low-3 domestic water use and May-September maximum temperature ranged from an $R^{2}$ of 0.01 (Gilroy, Calif.) to 0.86 (San Luis Obispo, Calif.). Only two cities, San Luis Obispo, Calif., and Wichita, Kans., had an $R^{2}$ of at least 0.60 (table 4). For these two cities, a direct relation was indicated in which low-3 domestic water use increased as May-September maximum temperature increased. For several of the cities, the strength of the relation between low-3 domestic water use and annual maximum temperature, as compared to the strength of the relation between low-3 domestic water use and May-September maximum temperature, was dissimilar (table 4).

For the relation between high-3 domestic water use and annual precipitation, the $R^{2}$ values ranged from 0.01 (Natchez, Miss.) to 0.84 (Alice, Tex.). In addition to Alice, Tex., the only other city with an $R^{2}$ of at least 0.60 was Miles City, Mont. (table 5). For these two cities, an inverse relation was
Table 4. Coefficients of determination $\left(R^{2}\right)$ for low-3 domestic per capita water use compared to three climatic variables for 15 selected U.S. cities, 2005-10.

[shading, $R^{2}$ value of 0.6 or greater; ( ), inverse relation]

\begin{tabular}{|c|c|c|c|}
\hline \multirow[b]{2}{*}{ City (fig. 1) } & \multicolumn{3}{|c|}{ Coefficients of determination $\left(R^{2}\right)$} \\
\hline & $\begin{array}{l}\text { Annual } \\
\text { precipita- } \\
\text { tion }\end{array}$ & $\begin{array}{c}\text { Annual } \\
\text { maximum } \\
\text { tempera- } \\
\text { ture }^{1}\end{array}$ & $\begin{array}{c}\text { May- } \\
\text { September } \\
\text { maximum } \\
\text { tempera- } \\
\text { ture }^{2}\end{array}$ \\
\hline Banning, Calif. & $(0.76)$ & 0.57 & 0.22 \\
\hline Gilroy, Calif. & .51 & .26 & .01 \\
\hline Paradise, Calif. & $(.80)$ & .64 & .11 \\
\hline San Luis Obispo, Calif. & .50 & .88 & .86 \\
\hline Watsonville, Calif. & .19 & .26 & .14 \\
\hline Atwood, Kans. & 0 & .31 & .14 \\
\hline Baldwin City, Kans. & .47 & .56 & .50 \\
\hline Hutchinson, Kans. & 0 & .08 & .03 \\
\hline Ulysses, Kans. & .64 & 0 & .50 \\
\hline Wichita, Kans. & .39 & .49 & .60 \\
\hline Natchez, Miss. & 0 & .10 & .54 \\
\hline Helena, Mont. & .70 & .07 & .20 \\
\hline Miles City, Mont. & .10 & .45 & .26 \\
\hline Alice, Tex. & $(.68)$ & .80 & .49 \\
\hline Dumas, Tex. & .09 & .71 & .05 \\
\hline
\end{tabular}

${ }^{1}$ Computed as the mean of monthly mean maximum temperatures.

${ }^{2}$ Computed as the mean of monthly mean maximum temperatures for May-September. 
Table 5. Coefficients of determination $\left(R^{2}\right)$ for high-3 domestic per capita water use compared to three climatic variables for 15 selected U.S. cities, 2005-10.

[shading, $\mathrm{R}^{2}$ value of 0.6 or greater; ( ), inverse relation]

\begin{tabular}{|c|c|c|c|}
\hline \multirow[b]{2}{*}{ City (fig. 1) } & \multicolumn{3}{|c|}{ Coefficients of determination $\left(R^{2}\right)$} \\
\hline & $\begin{array}{c}\text { Annual } \\
\text { precipita- } \\
\text { tion }\end{array}$ & $\begin{array}{c}\text { Annual } \\
\text { maximum } \\
\text { tempera- } \\
\text { ture }^{1}\end{array}$ & $\begin{array}{c}\text { May- } \\
\text { September } \\
\text { maximum } \\
\text { tempera- } \\
\text { ture }^{2}\end{array}$ \\
\hline Banning, Calif. & 0.24 & 0.08 & 0.01 \\
\hline Gilroy, Calif. & .04 & .36 & .31 \\
\hline Paradise, Calif. & .07 & .48 & .70 \\
\hline San Luis Obispo, Calif. & .29 & 0 & .05 \\
\hline Watsonville, Calif. & .17 & .23 & .11 \\
\hline Atwood, Kans. & .11 & .75 & .81 \\
\hline Baldwin City, Kans. & .40 & .27 & .25 \\
\hline Hutchinson, Kans. & .17 & .66 & .17 \\
\hline Ulysses, Kans. & .44 & .19 & .04 \\
\hline Wichita, Kans. & .31 & .38 & .47 \\
\hline Natchez, Miss. & .01 & .23 & .53 \\
\hline Helena, Mont. & .02 & .86 & .59 \\
\hline Miles City, Mont. & $(.68)$ & .79 & .86 \\
\hline Alice, Tex. & $(.84)$ & .80 & .68 \\
\hline Dumas, Tex. & .06 & .27 & .04 \\
\hline
\end{tabular}

${ }^{1}$ Computed as the mean of monthly mean maximum temperatures.

${ }^{2}$ Computed as the mean of monthly mean maximum temperatures for May-September.

indicated in which high-3 domestic water use increased as annual precipitation decreased. The $R^{2}$ values for the remaining 13 cities were less than 0.45 .

The relation between high-3 domestic water use and annual maximum temperature, as evidenced by the $R^{2}$ values, ranged from 0 (San Luis Obispo, Calif.) to 0.86 (Helena, Mont.). Besides Helena, Mont., other cities with an $R^{2}$ of at least 0.60 were Atwood, Kans., Hutchinson, Kans., Miles City, Mont., and Alice, Tex. (table 5). A direct relation was indicated for these five cities in which high-3 domestic water use increased as annual maximum temperature increased. The relation between high-3 domestic water use and May-September maximum temperature ranged from an $R^{2}$ of 0.01 (Banning, Calif.) to 0.86 (Miles City, Mont.). In addition to Miles City, Mont., other cities with an $R^{2}$ of at least 0.60 were Paradise, Calif., Atwood, Kans., and Alice, Tex. (table 5). For these four cities, a direct relation was indicated in which high-3 domestic water use increased as May-September maximum temperature increased. The strength of the relation between high-3 domestic water use and annual maximum temperature, as compared to the strength of the relation between high- 3 domestic water use and May-September maximum temperature, was similar for most of the cities (table 5).

Overall, it was determined that the climatic variables considered in this assessment potentially may be useful for estimating domestic water use for specific cities. However, given the frequently weak relation between domestic water use and the climatic variables, it also was apparent that nonclimatic factors were important determinants of domestic water use.

\section{Guidance for Estimating Domestic Water Use}

Estimation of domestic water use, expressed as a per capita rate, is useful for understanding current usage and planning for future water supply. Differences in per capita water use among water suppliers and changes with time can be related to factors such as climatic conditions, economics, or implementation of conservation measures. However, such explanatory variables are unlikely to provide a convenient method for prediction of per capita use rates through linear relations. The periodic collection of water-use data for a large enough sample of suppliers is critical for establishing ranges in actual water usage. Data collection allows for the development of gpcd averages, which often vary regionally or by year. These averages can be used to evaluate individual suppliers' usage and to estimate unreported use.

Several States included in this study collect annual water-use and population data that allows for calculation of per capita use. Since 2005, the Texas Water Development Board (TWDB) has calculated total municipal per capita use for approximately 800 water utilities that completed annual water-use surveys. In 2007, TWDB began requesting sales information for single- and multi-family residences; therefore, calculation of total and residential (domestic) gpcd values has been possible. Survey return rates from 2005-2009 were greater than 80 percent, and the median total gpcd ranged from 127 to 154 for responding utilities. More than 60 percent of the responding utilities have provided residential sales information, and the median domestic gpcd ranged from 86 to 88 during 2006-2009.

Collection of data with time can be useful for measuring larger trends in water use and how that use may affect available supplies. The California 20x2020 Water Conservation Plan (California Department of Water Resources and others, 2010) established 2005 baseline gped for each of 10 hydrologic regions in the state, using water production and sales data compiled through the Department of Water Resources' annual Public Water Systems Survey. Baseline gpcd values for total and residential use are highest in the arid inland regions and lowest in the cooler coastal regions where water supplies are more limited and conservation efforts have already been implemented. Through continued data collection and refinement of the baseline values, progress towards legislated conservation goals can be measured. 
The Public Service Commission of Wisconsin (PSC) collects detailed annual reports from more than 580 regulated public water utilities. Data include total withdrawals, retail sales volumes, water loss, population served, and water rates. PSC data indicate that average residential sales volume decreased from 63,100 gallons per customer in 2005 to 51,970 gallons per customer in 2010 , whereas average residential water rates have steadily increased. Total volume of water pumped for public supply has decreased each year since 2007 (Public Service Commission of Wisconsin, 2011).

In Kansas, most public water-supply systems are required to have permits to appropriate water, and file annual reports with the Kansas Department of Agriculture's Division of Water Resources. Information collected on water production, sales, and unaccounted for water has been used to develop per capita water use averages for eight regions of the state, corresponding to water sources and climatic conditions. Regional average rates of total per capita water use are used to evaluate the water usage and water rights of individual systems. Gpcd averages for Kansas utilities have been calculated since 1987 using residential and commercial sales, public uses, and losses. Average Kansas gpcd based on these combined amounts varies somewhat from year to year, but overall has declined from 139 in 1998 to 114 in 2010 (Kansas Water Office and others, 2000; Kansas Department of Agriculture and U.S. Geological Survey, 2012).

The USGS NWUIP reports provide estimates of total public supply and domestic water use for the whole population in the United States at 5-year intervals. However, information on water use, customer sales, and population is not routinely reported for every water supplier in every State, and selfsupplied domestic water use is not reported at all. As a result, some estimation of unreported uses is necessary to provide an accounting of total water use for an aggregate area such as a county, State, or the Nation. The following sections describe data collection and use of per capita coefficients in State and national programs, specifically for estimating public supply withdrawals, domestic deliveries from public supply, and domestic self-supplied use as part of the 5-year compilations. This guidance is provided for the benefit of USGS personnel generating domestic estimates as well as anyone using the national data to describe trends in per capita water use in the United States.

\section{Public Supply}

For most States, public supply and domestic water-use data are obtained in part through State reporting programs or surveys of public water suppliers. Where data are lacking or incomplete, estimation of public supply withdrawals and domestic deliveries is common. Per capita averages for total public supply use and domestic deliveries can be useful tools for evaluating reported data and for estimating unreported data, if reliable estimates of population served are possible. The percentage of total public supply that is delivered for domestic use is another useful tool for quality assurance and for developing accurate estimates.

The best information on total withdrawals is reported by actual suppliers and includes information on wholesale water purchases and sales. Obtaining this information from the largest suppliers (at a minimum) is important for compilation of total public water supply use. Estimation of withdrawals using per capita coefficients is impractical for large or complex systems because these coefficients cannot account for wholesale water transfers or for unique customer characteristics, such as large industries or seasonal populations. System losses and water used for public services also are difficult to estimate for large water suppliers through coefficients because of the variability inherent in these components of use. Per capita coefficients can be used for estimating withdrawals for smaller systems for which the source of water is known and a population served can be determined. Coefficients used for estimation of total withdrawals should be based on total use by

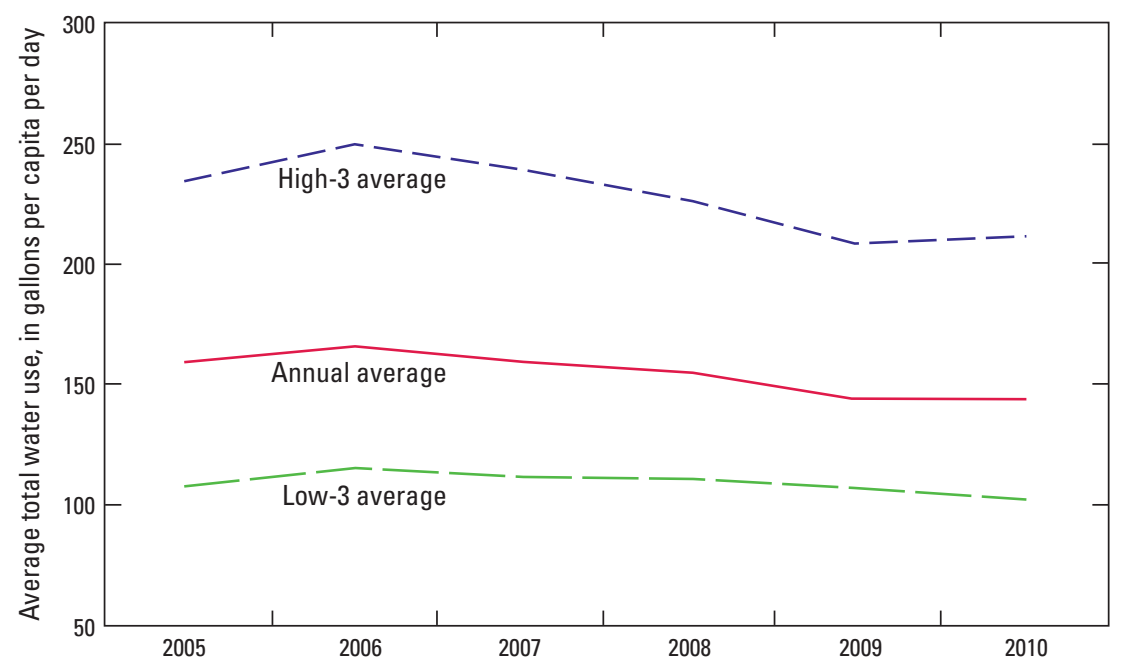

Figure 11. Average annual, high-3, and low-3 total per capita water use for selected U.S. cities, 2005-10. 


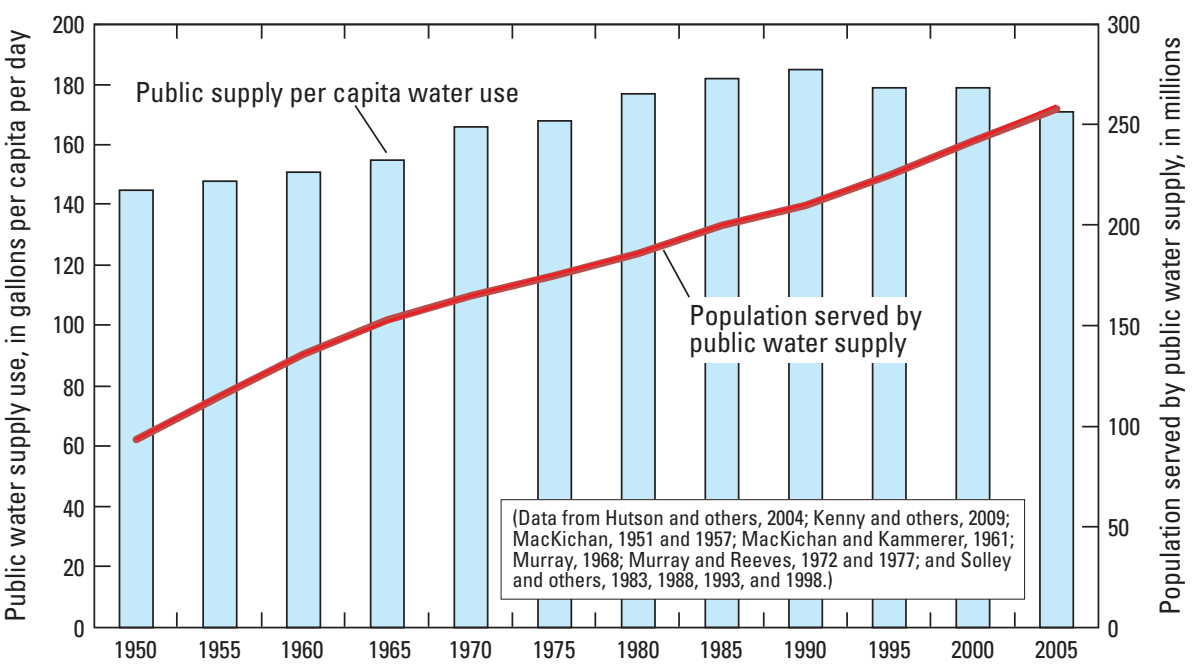

Figure 12. Public supply per capita water use and population served, United States, 1950-2005.

similar sized systems in similar areas, and account for customer use and losses.

The average total per capita use for the 19 selected cities that were able to provide monthly production data for all 6 years is shown in figure 11. Annual, high-3, and low-3 averages are shown for each year. Average total gpcd declined from 2006 to 2010 for all three measures: from 167 to $145 \mathrm{gpcd}(-13$ percent) for annual use, from 115 to $102 \mathrm{gpcd}$ (-11 percent) for low-3 use, and from 250 to $211 \mathrm{gpcd}$ (-16 percent) for high-3 use. The decline was greatest for the high-3 average, indicating some attenuation of peak water use.

Average total public supply per capita use for the United States for 1950-2005, as estimated in the USGS 5-year reports, is shown in figure 12. The national average public supply gpcd increased steadily from 145 gpcd in 1950 to a peak of 185 in 1990, then decreased to 171 in 2005. In 2005, the average public supply gped among the 50 States ranged from 105 gpcd in Vermont to 303 gpcd in Nevada (Kenny and others, 2009).

\section{Domestic Deliveries}

USGS compiles domestic deliveries for all public water suppliers, including those that withdraw water and those that purchase water from other suppliers. The best information on domestic deliveries is reported by actual suppliers able to separate single-family and multi-family use from other sales. Such information is not routinely obtained through reporting programs, and cannot easily be determined by many suppliers, so estimation of domestic deliveries is common. There are two primary methods for estimating unreported domestic deliveries. Estimates may be based on an amount of water (total production or sales) and average percentage domestic, or on the population served and average per capita use. The two methods are complementary, each providing a check of the other.
Calculations of per capita water use and percentage domestic deliveries can provide useful quality assurance checks for aggregate data on population served and domestic deliveries in areas, such as a county or State. An anomalous domestic delivery per capita value may indicate that the estimate of population served needs adjustment. Unless there are substantial transfers of water into or out of an area, the domestic percentage of total public supply withdrawals should be reasonable. USGS estimates of domestic deliveries and population served for 2005 yielded State domestic delivery per capita averages ranging from 51 gpcd in Maine to 189 gpcd in Nevada, with a national average of 99 gpcd (Kenny and others, 2009). The national average for domestic delivery water use was 105 gpcd in 1990 (Solley and others, 1993), $101 \mathrm{gpcd}$ in 1995 (Solley and others, 1998), and not measured for all States in 2000.

\section{Domestic Deliveries Based on Percentage of Total Production or Sales}

Amounts of water used by domestic customers of a water supply system are often estimated if sales to domestic users are not reported. Domestic use may be estimated as a percentage of the total water produced, or as a percentage of total retail sales.

If sufficient information on withdrawals and wholesale transfers is available, domestic deliveries may be estimated as a percentage of a city's total production. Total production is defined as the amount of water produced and (or) purchased, minus wholesale transfers (see section on Data Calculations). This method assumes average distribution of use among domestic use, commercial and industrial customers, public use, and losses. Domestic deliveries in the selected cities of this study ranged from a median of 33 percent of total use in Natchez, Miss., which has large percentages of commercial and other water uses, to 71 percent of total use in Paradise, 
Calif., which has few commercial and no industrial sales. On average, domestic deliveries in the selected cities represented 56 percent of the total water production. On a national scale, domestic deliveries represented an average 56 percent of total public supply withdrawals in 1995 (Solley and others, 1998). National estimates of domestic deliveries in 2005 averaged 58 percent of total public supply withdrawals (Kenny and others, 2009).

If information on total retail sales is available, average percentages can be used to separate domestic deliveries from commercial and industrial deliveries. In general, small systems are more likely to serve primarily residential customers than large systems, in which a larger part of the customer base is composed of commercial and industrial users. According to the 2006 Community Water System Survey, on average, residential customers accounted for 69 percent of retail water deliveries, and nonresidential customers accounted for 31 percent (U.S. Environmental Protection Agency, 2009). Domestic deliveries in the selected cities ranged from a median of 52 percent to 85 percent of total deliveries, with an average of 71 percent. Domestic use was higher than this average percentage in most of the cities with a population of less than 10,000. An exception was Baldwin City, Kans., whose small resident population and college campus tend to increase the percentage of nonresidential sales. Few of the selected cities had industrial sales, and industrial sales that were identified represented small percentages of total use. Estimation of domestic deliveries as a percentage of total sales in water systems with large industrial sales requires accounting for those large sales in the percentage of nonresidential use.

When estimating domestic deliveries using average percentages of the total use or total sales, the resulting domestic per capita use should be compared to average gpcd rates for similarly sized water suppliers in similar geographic locations that have provided actual data. This comparison can serve as a quality-assurance check of the percentages used and of the population estimate. A domestic gped that is substantially less than expected may indicate that actual domestic deliveries are a larger percentage of the total than was estimated, and (or) that the estimate of population served was too large. A domestic gpcd that is substantially greater than expected may indicate that actual domestic deliveries are a smaller percentage of the total than was estimated, and (or) that the population estimate was too small.

\section{Domestic Deliveries Based on Per Capita Use}

The estimate of population served by a water supplier can be used with a per capita coefficient derived from average per capita water use to calculate domestic deliveries. The appropriateness of using a single coefficient to estimate domestic deliveries will vary by State and may only be applicable locally. For example, in this study it was indicated that use of a single coefficient would possibly be more appropriate for small cities in Wisconsin, a State with less geographic variability in climatic conditions and also in domestic per capita water use. Single coefficients would not be appropriate for California or Kansas, States with a greater geographic range in climatic conditions and average per capita use. Average gpcd rates used should be similar to those observed from actual water suppliers in similar geographic locations.

For individual water suppliers, estimates of domestic deliveries that are based on per capita coefficients should be compared to any available information on total withdrawals or sales to ensure that the domestic deliveries, as a percentage of these totals, are reasonable for the size of water supplier. If the percentage of domestic deliveries is comparatively small (for example, less than 30 percent of total use) there may be larger than average use for non-residential sales or other uses, or the gpcd coefficient or the estimate of population served may be too low. If the percentage of domestic deliveries is comparatively large (for example, greater than 75 percent of total use) the gpcd coefficient or the estimate of population served may be too large. An exception to this latter example is the very small water system, in which domestic customers comprise the largest use, and in which losses can be minimal.

\section{Domestic Self-Supplied Water Use}

Most domestic self-supplied use in the United States is from groundwater (Kenny and others, 2009). In some areas, self-supplied populations may obtain water from springs, rainwater catchment, or hauled water from another source of supply. Few States require permitting for domestic water use, and such uses are rarely metered. As a result, domestic selfsupplied water use is calculated in each State using estimates of unserved population and per capita coefficients. For most States, the estimate of self-supplied population is determined as the difference between the total population and the aggregate population served by public water suppliers. Thus, accounting for population served directly affects the estimate of domestic self-supplied water use.

Coefficients used to estimate domestic self-supplied water use vary by State and often by county. Average State domestic self-supplied water use in 2005 ranged from 50 gpcd in Kentucky to 206 gpcd in Nevada, and generally was lowest in the northern and eastern States and largest in the mountain and western States. The national average for domestic selfsupplied water use in 2005 was 89 gpcd (Kenny and others, 2009).

Selection of appropriate coefficients for domestic self-supplied water use is made by each USGS Water Science Center and described in unpublished documentation for each 5-year NWUIP report. For about 65 percent of the States (including Mississippi, Montana, and Texas), domestic self-supplied water use in 2005 was estimated using standard statewide coefficients that were based on previously published reports or generally accepted values. For these States, coefficients ranged from 50 to 165 gpcd; the median value was 76 gpcd. The advantage of this method is its simplicity 
because in most States a small minority of the population is self-supplied, and there are few opportunities to measure their use. Self-supplied populations may use less water per capita than populations on public supply because of limitations on water supply, pump rates, or storage. Outdoor water needs may not be considered, or may be provided by separate sources than indoor water needs. Conversely, self-supplied populations may use more water per capita than publicsupplied populations because they generally occupy singlefamily homes and are not billed for water service or subject to watering restrictions. The disadvantage of using standard coefficients is that they are unlikely to capture any regional or temporal trends in domestic water use.

About 35 percent of the States (including California, Kansas, and Wisconsin) used per capita coefficients based on domestic delivery data to estimate domestic self-supplied withdrawals by county for 2005 . This method is based on the assumption that the self-supplied population uses water at the same rate as the population served by public supply. Average domestic self-supplied per capita use for these States ranged from 52 to $206 \mathrm{gpcd}$, with a median of $98 \mathrm{gpcd}$. The primary reason that the average gpcd is larger when based on domestic delivery data is that many of the States using delivery data to develop self-supplied domestic coefficients are in the arid west. The advantage of this method is that the coefficients are related to actual rates of metered usage and can represent different regional use patterns. The disadvantage to developing coefficients from observed data is that it takes time to collect data, and there is no guarantee that self-supplied households use water at the same rate as those on public supply.

In arid western States, the exemption of groundwater used for domestic and livestock purposes from permitting processes can potentially affect groundwater availability, surface flows, and water quality (Bracken, 2010). In specific areas with scarce resources and increasing numbers of households with private wells, an assessment of domestic water use may require metering of households or development of more specific per capita coefficients to estimate water demand.

\section{Additional Considerations for National Data Collection}

Quantification of domestic water use throughout the United States requires estimation because complete inventories are not available. An evaluation of the NWUIP completed by the National Research Council (2002) recommended improvements to the 5-year summaries through statistical sampling and estimation techniques, as well as determination of standard error of the estimates. Collection of actual data is an essential element for a sampling program, development of estimation methods, and determination of error in the estimates.

Collection of information on household water use has typically depended on water suppliers' ability to provide billing records specifically for residential customers. This information can be difficult to collect from a random sample because of differences in record keeping, availability of staff to respond to requests, and the fact that water suppliers are, in most places, under no obligation to provide such data. The most effective means for collecting domestic water-use information for this study was through existing State programs. There are advantages to minimizing the number of data requests from individual public suppliers, and to having a framework for periodic reporting. Among the States, variations in the quantity and quality of data collected are unavoidable, in part, because of differences in priorities, laws, and budgets.

Per capita coefficients derived from water use are useful for comparing domestic use geographically and temporally. Development of reliable coefficients depends on data collection from a sufficiently large sample to identify any regional differences in per capita use. Evaluation of changes in use with time requires that data collection be repeated on a regular basis, so that any changes in per-capita use may be evaluated in comparison to other variables such as annual climatic conditions, rate increases, or implementation of conservation efforts. Continued estimation of population served is essential for the development of representative per capita coefficients, and also for the subsequent use of these coefficients to estimate unreported water use.

Comparison of domestic per capita water use for individual cities with variables describing socioeconomic conditions, climatic conditions, and cost of water resulted in inconclusive relations. Rates of water use may be affected by a combination of many factors. Collection and interpretation of water-use data from water suppliers, particularly if sustained for a period of time, provides useful information that can be compared with other variables.

\section{Summary and Conclusions}

A 3-year study by the U.S. Geological Survey was begun in 2009 to describe recent domestic per capita water use in selected U.S. cities, investigate variables that potentially affect domestic water use, and provide guidance for estimating domestic water use. Study objectives were met by the collection and analysis of 2005-2010 domestic water-use and related socioeconomic and climatic data for 21 selected U.S. cities. The results of this study are summarized below:

1. Domestic per capita water use for the 21 selected cities ranged from a median annual average of 43 to $177 \mathrm{gpcd}$.

2. In terms of year-to-year variability in domestic per capita water use for the 21 selected cities, the difference from the median ranged from \pm 7 to \pm 26 percent with an overall median variability of \pm 14 percent.

3. As a percentage of total annual water use, median annual domestic water use for the 21 selected cities ranged from 33 to 71 percent with an overall median of 57 percent. 
4. Median low-3 domestic per capita water use for 16 selected cities ranged from 40 to 100 gpcd.

5. Median high-3 domestic per capita water use for 16 selected cities ranged from 53 to 316 gpcd.

6. In general, the median domestic water use as a percentage of the median total water use for 16 selected cities was similar for the low-3 and high-3 periods.

7. Statistical analyses of combined data for 20 selected cities indicated that none of the socioeconomic variables, including cost of water, were potentially useful as determinants of domestic water use at the national level.

8. Statistical analyses indicated that specific socioeconomic variables may be useful for the estimation of domestic water use at the State or local level and different socioeconomic variables may be useful in different States.

9. Statistical analyses indicated that specific climatic variables may be useful for the estimation of domestic water use for some, but not all, of the 21 selected cities.

10. National average public supply per capita water use declined from 185 gpcd in 1990 to 171 gpcd in 2005. National average domestic delivery per capita use declined from 105 gpcd in 1990 to 99 gpcd in 2005.

11. The average total per capita water use in 19 of the 21 selected cities declined from 167 gpcd in 2006 to 145 gpcd in 2010. Average per capita water use measured during the 3 months of lowest use each year declined from 115 to 102 gpcd, and average per capita use measured during the 3 months of highest use declined from 250 to 211 gpcd.

12. Continued collection of data on water deliveries to domestic populations, as well as updated estimates of the population served by these deliveries, is recommended for determination of regional and temporal trends in domestic per capita water use. Declines in various measures of per capita use have been observed in recent years for several States with municipal water use data-collection programs.

13. Average domestic delivery per capita use among all States ranged from 51 to 189 gpcd in 2005.

14. Domestic self-supplied water use historically has not been metered. Estimates of domestic self-supplied water use are made using estimates of the population that is not served by public water suppliers and per capita coefficients. For 2005, average domestic self-supplied per capita use among all States ranged from 50 to 206 gpcd. The median self-supplied domestic per capita use was 76 gpcd for States in which standard statewide coefficients were used, and 98 gpcd for States in which coefficients were based on domestic deliveries from public supply.
15. In specific areas with scarce resources or increasing numbers of households with private wells, an assessment of domestic water use may require metering of households or development of more specific per capita coefficients to estimate water demand.

\section{References Cited}

Bracken, Nathan, 2010, Exempt well issues in the West: Lewis and Clark Law School's Environmental Law online, 47 p.,

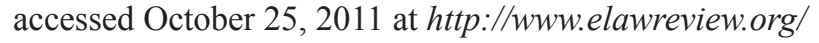
elaw/401/report_exempt_well_issues_in_t.html.

California Department of Water Resources, California State Water Resources Control Board, California Bay-Delta Authority, California Energy Commission, California Department of Public Health, California Public Utilities Commission, California Air Resources Board, California Urban Water Conservation Council, and U.S. Bureau of Reclamation, 2010, Final 20x2020 Water Conservation Plan: Sacramento, Calif., 60 p., accessed March 30, 2012, at http://www.water.ca.gov/wateruseefficiency/sb7/ docs/20x2020plan.pdf.

Cohen, M.J., 2011, Municipal deliveries of Colorado River basin water: Oakland, Calif., Pacific Institute, 63 p.

Helsel, D.R., and Hirsch, R.M., 1992, Statistical methods in water resources: Amsterdam, Elsevier Science Publ., 529 p.

Horn, M.A., Moore, R.B., Hayes, Laura, and Flanagan, S.M., 2008, Methods for and estimates of 2003 and projected water use in the Seacoast region, southeastern New Hampshire: U.S. Geological Survey Scientific Investigations Report 2007-5157, 81 p.

Hutson, S.S., Barber, N.L., Kenny, J.F., Linsey, K.S., Lumia, D.S., and Maupin, M.A., 2004, Estimated use of water in the United States in 2000: U.S. Geological Survey Circular 1268, $46 \mathrm{p}$.

Kansas Department of Agriculture and U.S. Geological Survey, 2012, Kansas municipal water use 2010: Topeka, Kansas, 40 p.

Kansas Water Office, Kansas Department of Agriculture, and U.S. Geological Survey, 2000, 1998 Kansas municipal water use: Topeka, Kansas, 74 p.

Kenny, J.F., Barber, N.L., Hutson, S.S., Linsey, K.S., Lovelace, J.K., and Maupin, M.A., 2009, Estimated use of water in the United States in 2005: U.S. Geological Survey Circular 1344, $52 \mathrm{p}$.

MacKichan, K.A., 1951, Estimated use of water in the United States, 1950: U.S. Geological Survey Circular 115, 13 p. 
MacKichan, K.A., 1957, Estimated use of water in the United States, 1955: U.S. Geological Survey Circular 398, 18 p.

MacKichan, K.A., and Kammerer, J.C., 1961, Estimated use of water in the United States, 1960: U.S. Geological Survey Circular 456, 26 p.

Mayer, P.W., DeOreo, W.B., Opitz, E.M., Kiefer, J.C., Davis, W.Y., Dziegielewski, Benedykt, and Nelson, J.O., 1999, Residential end uses of water: Denver, Colo., American Water Works Association Research Foundation, 310 p.

Murray, C.R., 1968, Estimated use of water in the United States, 1965: U.S. Geological Survey Circular 556, 53 p.

Murray, C.R., and Reeves, E.B., 1972, Estimated use of water in the United States, 1970: U.S. Geological Survey Circular 676, $37 \mathrm{p}$.

Murray, C.R., and Reeves, E.B., 1977, Estimated use of water in the United States, 1975: U.S. Geological Survey Circular 765, $37 \mathrm{p}$.

National Research Council, 2002, Estimating water use in the United States-A new paradigm for the National Water-Use Information Program: Washington, D.C., National Academy Press, $176 \mathrm{p}$.

Public Service Commission of Wisconsin, 2011, 2011 Wisconsin Water Fact Sheet: Madison, Wis., 2 p., accessed October 26, 2011, at http://psc.wi.gov/conservation/ documents/WaterFactSheet.pdf.

Solley, W.B., Chase, E.B., and Mann, W.B., IV, 1983, Estimated use of water in the United States in 1980: U.S. Geological Survey Circular 1001, 56 p.

Solley, W.B., Merk, C.F., and Pierce, R.R., 1988, Estimated use of water in the United States in 1985: U.S. Geological Survey Circular 1004, 82 p.
Solley, W.B., Pierce, R.R., and Perlman, H.A., 1993, Estimated use of water in the United States in 1990: U.S. Geological Survey Circular 1081, 76 p.

Solley, W.B., Pierce, R.R., and Perlman, H.A., 1998, Estimated use of water in the United States in 1995: U.S. Geological Survey Circular 1200, $71 \mathrm{p}$.

U.S. Census Bureau, 2010, 2005-2009 American Community Survey 5-year estimates: accessed March 30, 2012, at http:// factfinder2.census.gov/faces/nav/jsf/pages/index.xhtml.

U.S. Environmental Protection Agency, 2009, 2006 Community Water System Survey, Volume I-Overview: U.S. Environmental Protection Agency, Office of Water, 57 p.

Utah Division of Water Resources, 2001, Identifying residential water use-Survey results and analysis of residential water use for thirteen communities in Utah: Salt Lake City, Utah Division of Water Resources, 56 p.

Utah Division of Water Resources, 2010, 2009 Residential water use: Salt Lake City, Utah Division of Water Resources, 37 p.

Vickers, A.L., 2001, Handbook of water use and conservation-Homes, landscapes, businesses, industries, farms: Amherst, Mass., WaterPlow Press, 446 p.

Weather Warehouse, 2011, 2005-2010 historical monthly weather data: accessed October 22, 2011 at http:// weather-warehouse.com/WeatherHistoryListing/ monthlyWeatherDataStart.html. 

Appendixes 


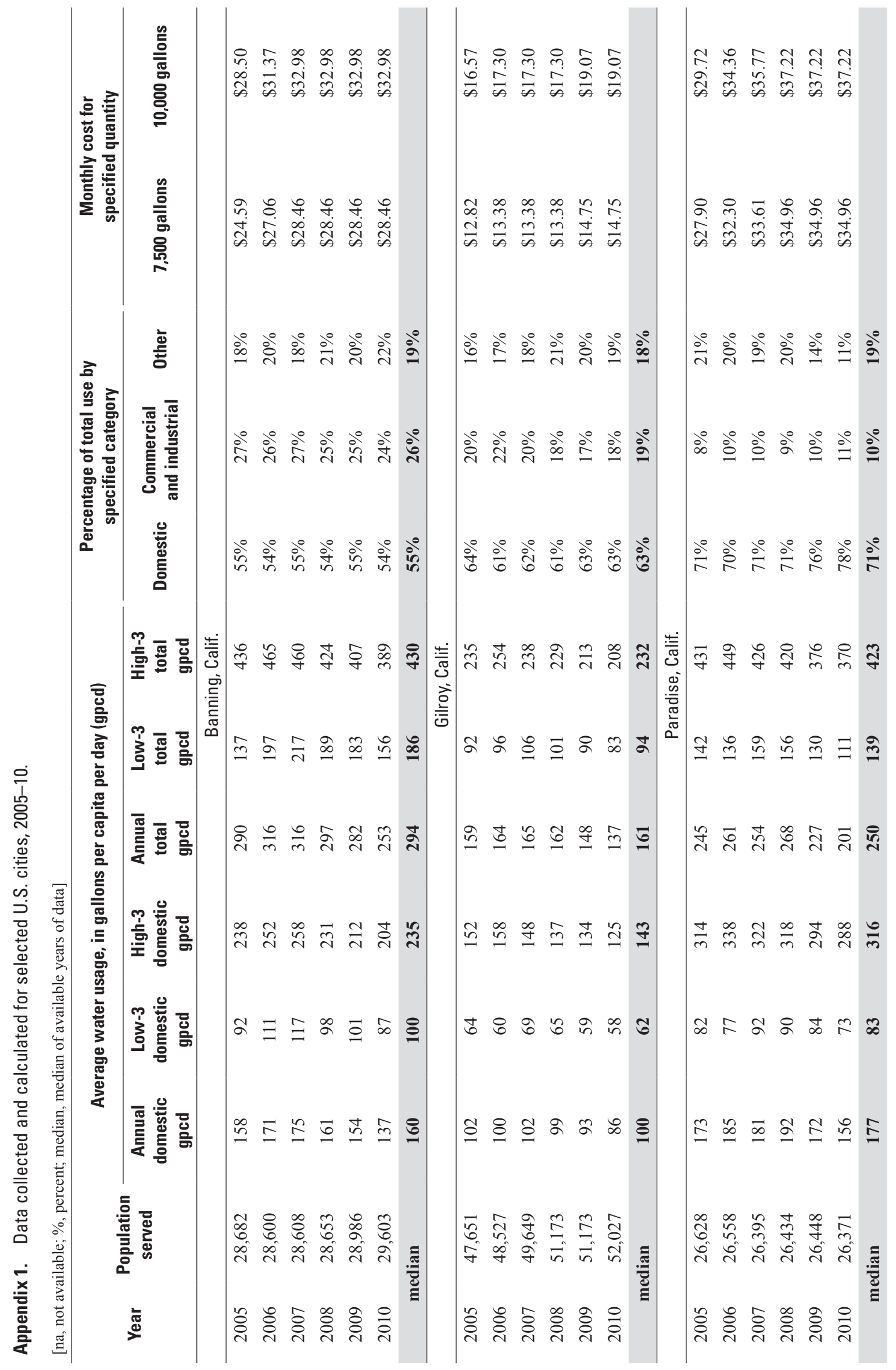




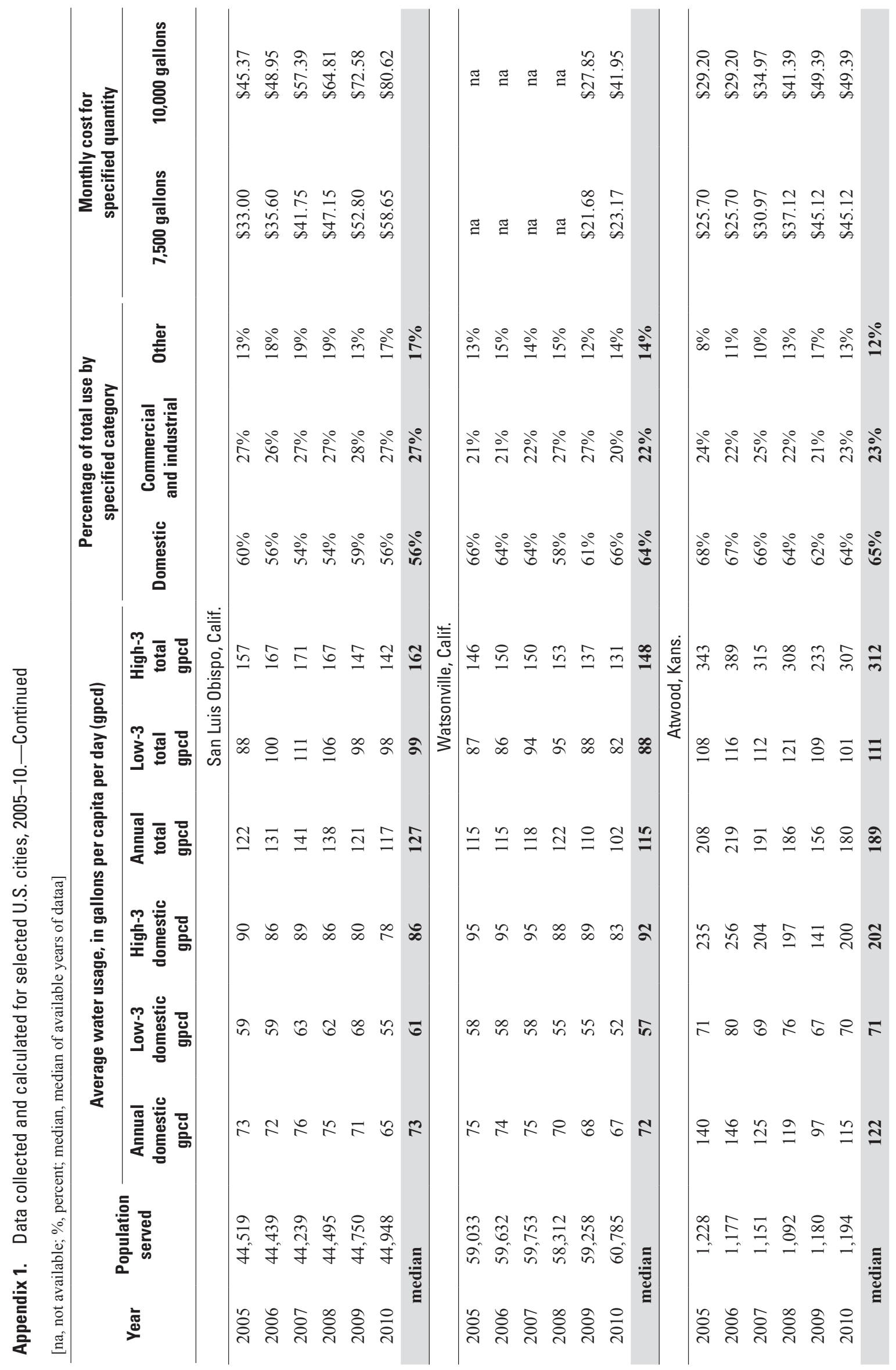




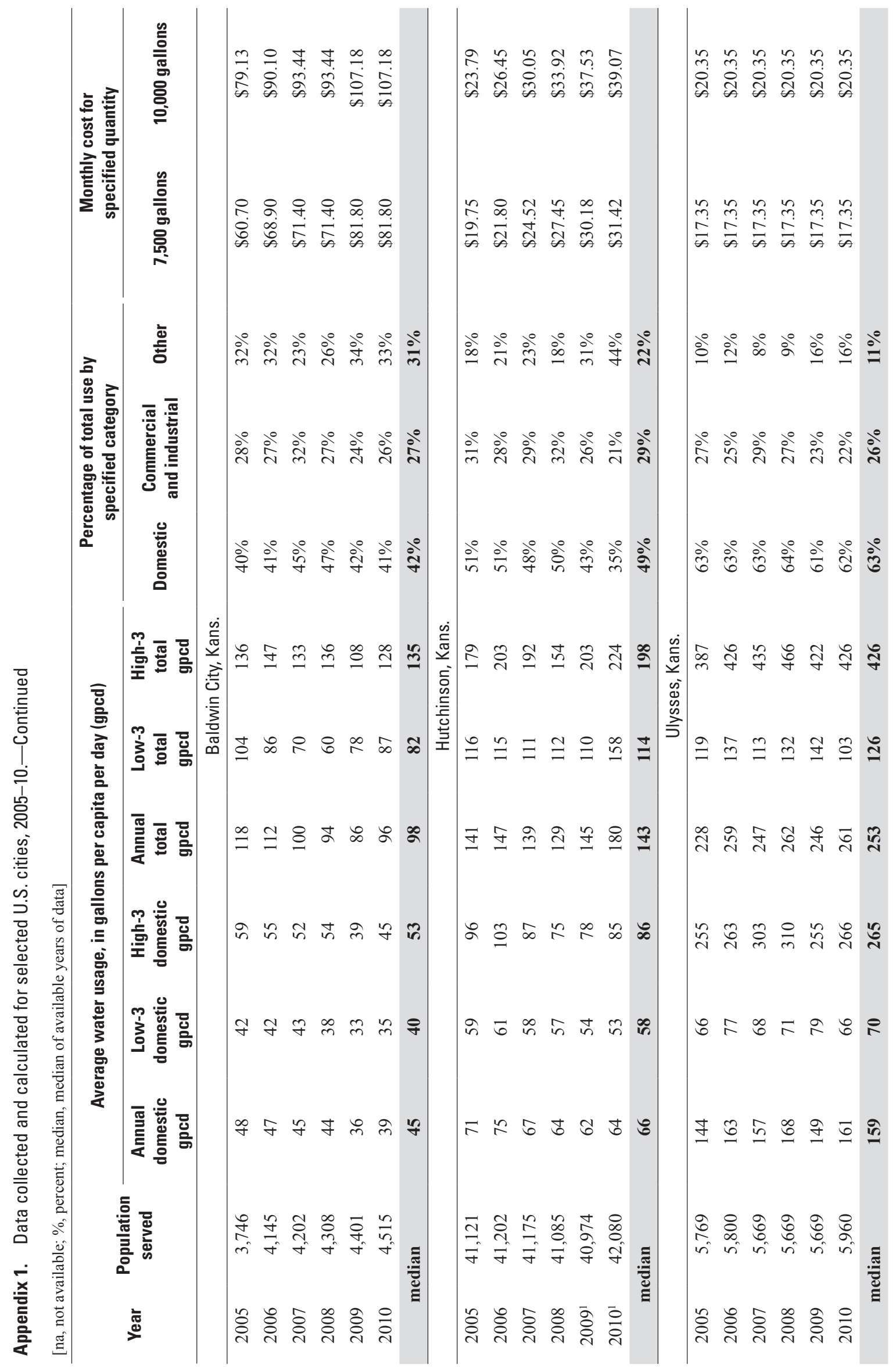




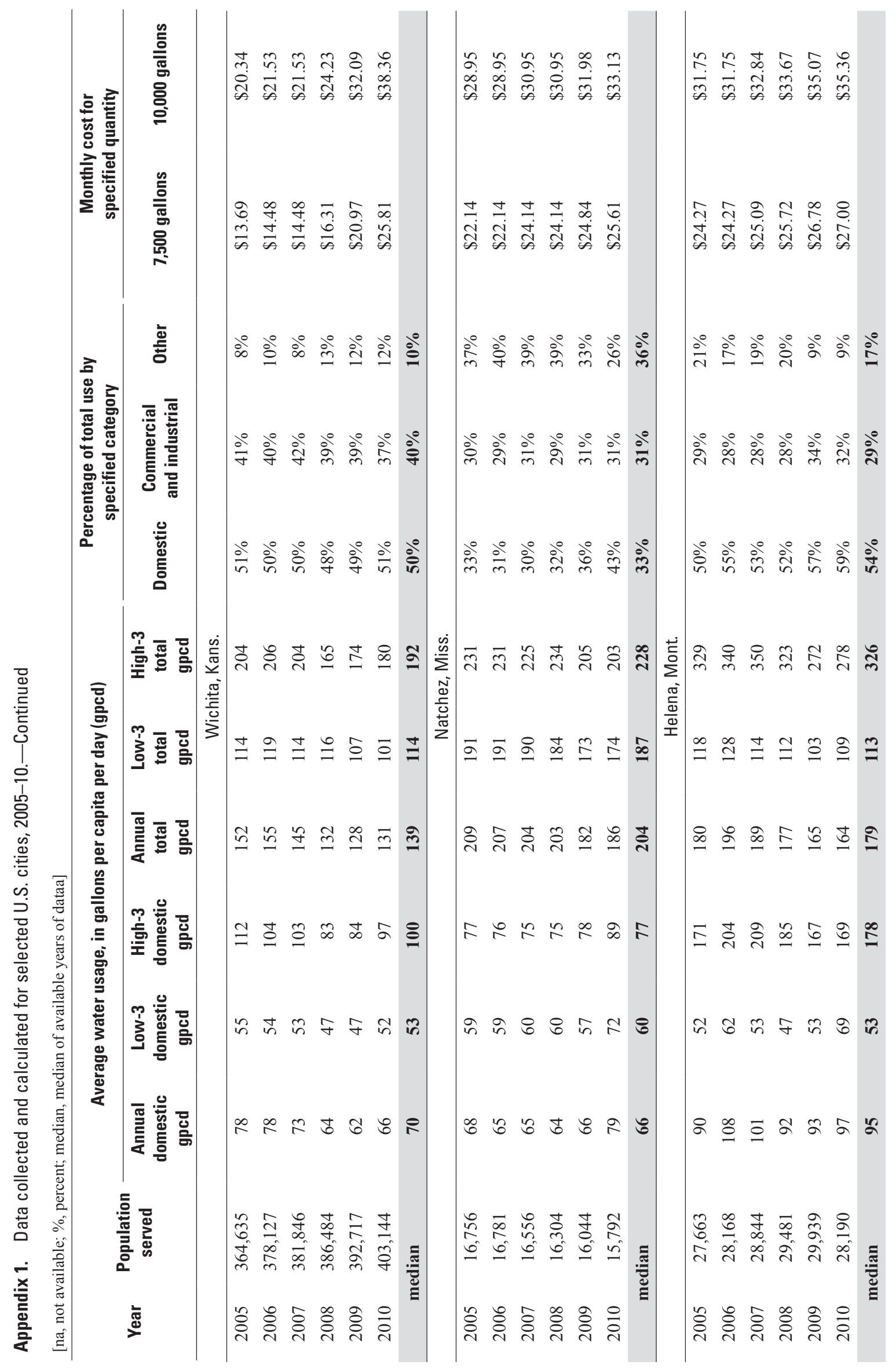




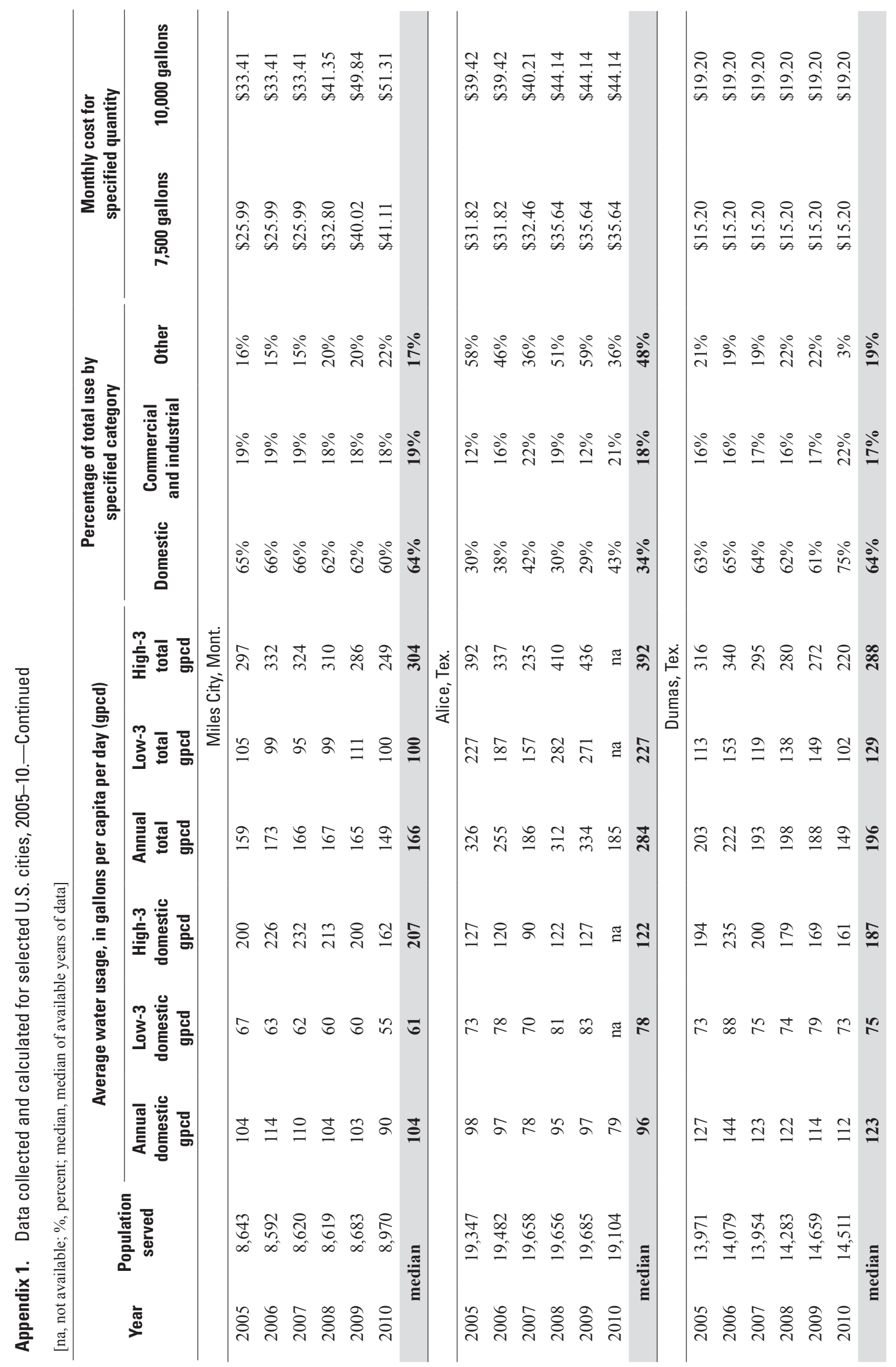




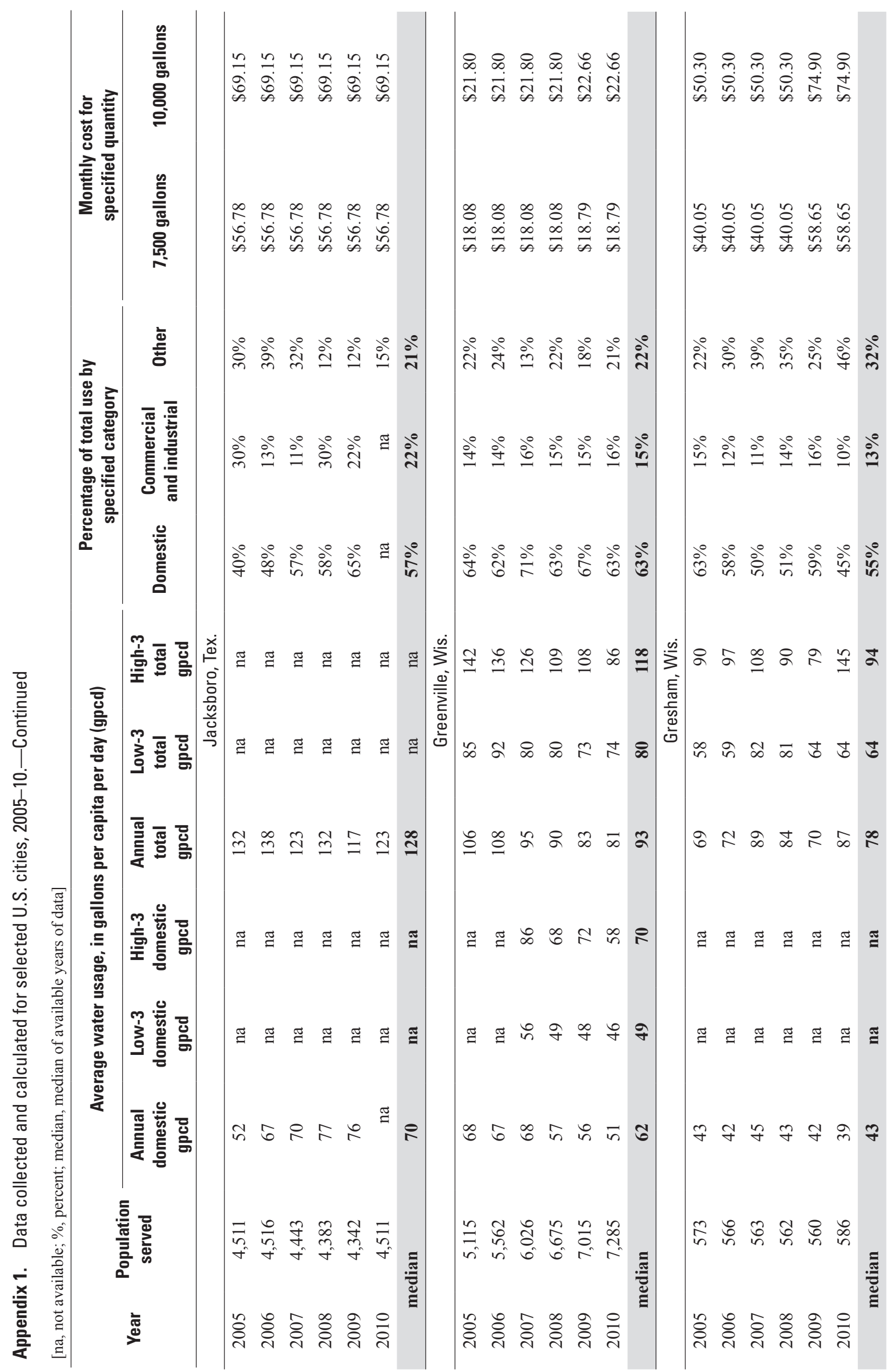




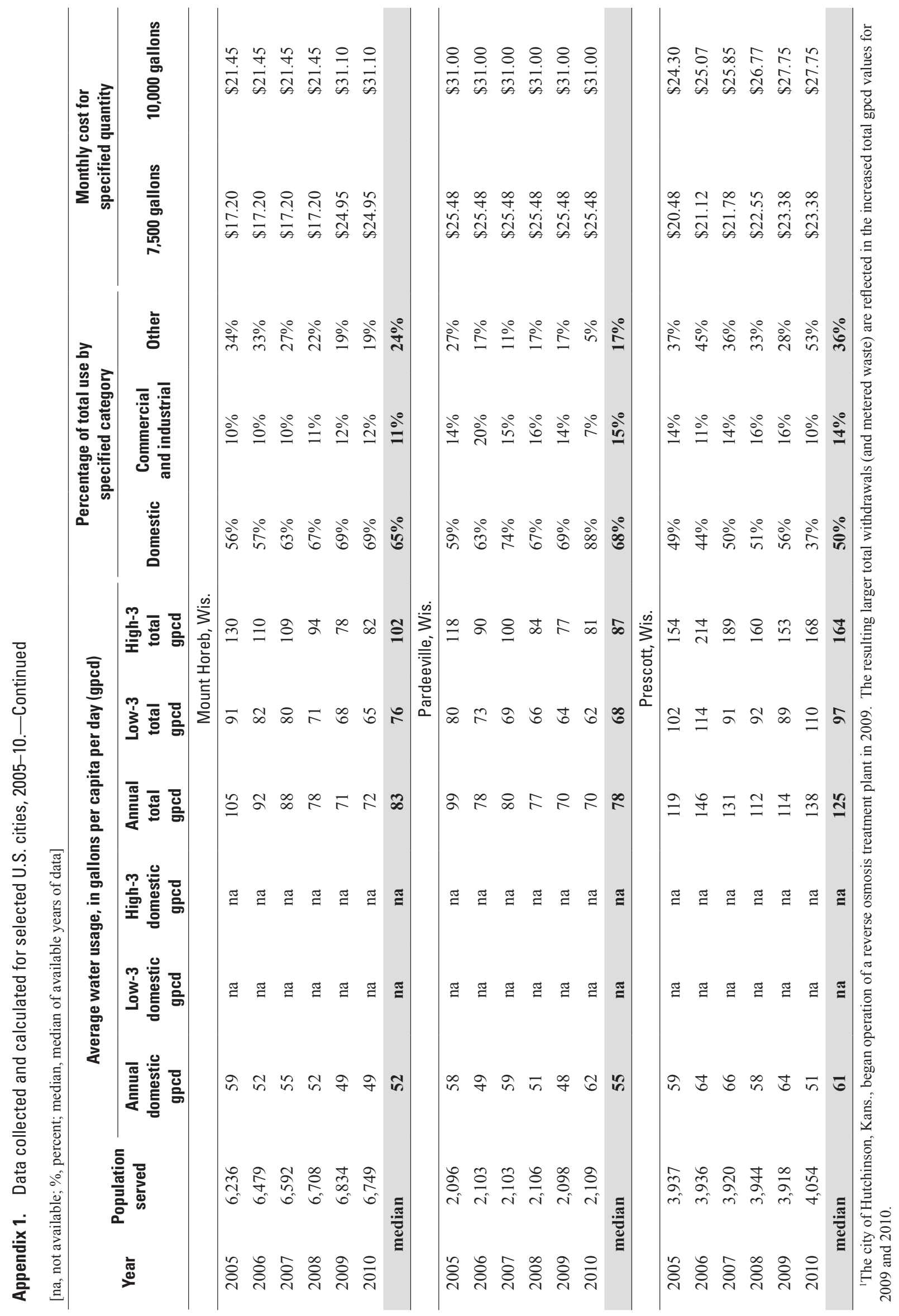


Appendix 2. Weather stations used for selected U.S. cities.

\begin{tabular}{lll}
\hline \multicolumn{1}{c}{ City (fig. 1) } & \multicolumn{1}{c}{$\begin{array}{c}\text { Weather station city } \\
\text { and State }\end{array}$} & \multicolumn{1}{c}{ Weather station name } \\
\hline Banning, Calif. & Cathedral City, Calif. & Palm Springs Rgnl Arpt \\
Gilroy, Calif. & Gilroy, Calif. & Gilroy \\
Paradise, Calif. & Paradise, Calif. & Paradise \\
San Luis Opispo, Calif. & San Luis Opispo, Calif. & McChesney Field \\
Watsonville, Calif. & Salinas, Calif. & Salinas No. 2 \\
Atwood, Kans. & Atwood, Kans. & Atwood 2 Sw \\
Baldwin, Kans. & Lawrence, Kans. & Clinton Lake \\
Hutchinson, Kans. & Hutchinson, Kans. & Hutchinson 2 E \\
Ulysses, Kans. & Ulysses, Kans. & Ulysses 3 Ne \\
Wichita, Kans. & Wichita, Kans. & Wichita Mid Continent Arpt \\
Natchez, Miss. & Washington, Miss. & Natchez \\
Helena, Mont. & Helena, Mont. & Helena Rgnl Arpt \\
Miles City, Mont. & Miles City, Mont. & Miles City F Wiley Field \\
Alice, Tex. & Alice, Tex. & Alice Intl Arpt \\
Dumas, Tex. & Dumas, Tex. & Dumas \\
Jacksboro, Tex. & Jacksboro, Tex. & Jacksboro \\
Greenville, Wis. & Appleton, Wis. & Appleton \\
Gresham , Wis. & Shawano, Wis. & Shawano 2 Sw \\
Mt. Horeb, Wis. & Dodgeville, Wis. & Dodgeville \\
Pardeeville, Wis. & Portage, Wis. & Portage \\
Prescott, Wis. & River Falls, Wis. & River Falls \\
\hline
\end{tabular}


Publishing support provided by:

Rolla Publishing Service Center

For additional information concerning this publication, contact: Director, USGS Kansas Water Science Center

4821 Quail Crest Place

Lawrence, KS 66049

(785) 842-9909

Or visit the Kansas Water Science Center Web Site at: http://ks.water.usgs.gov 



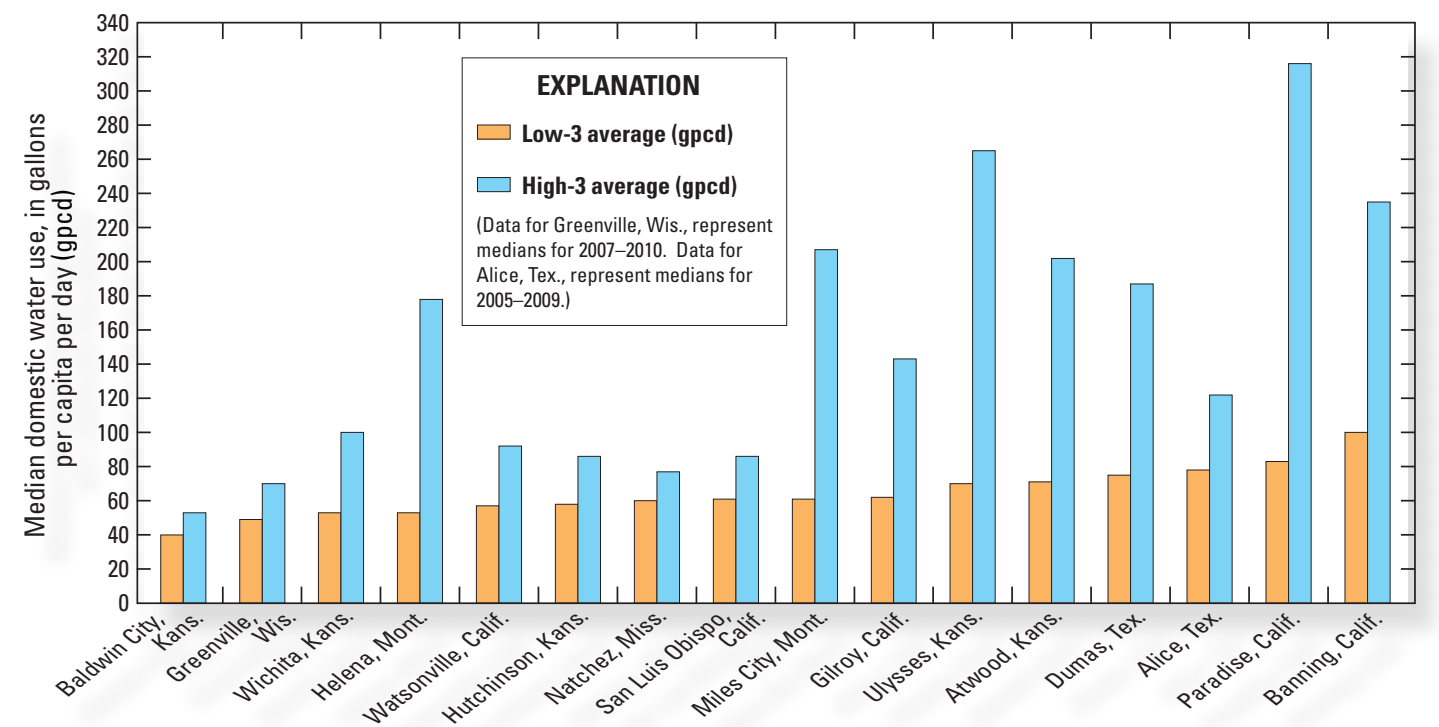

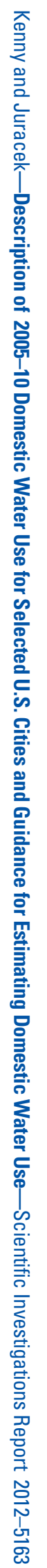

